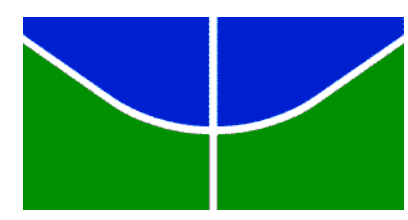

UNIVERSIDADE DE BRASÍLIA (UNB)

FACULDADE DE ADMINISTRAÇÃO, CONTABILIDADE, ECONOMIA E GESTÃO DE POLIITICAS PÚBLICAS (FACE)

PROGRAMA DE PÓS-GRADUAÇÃO EM ADMINISTRAÇÃO (PPGA)

Alexandre Leite dos Santos

DETERMINANTES DAS CESSÕES DE DIREITOS CREDITÓRIOS NO SETOR BANCÁRIO BRASILEIRO 


\section{DETERMINANTES DAS CESSÕES DE DIREITOS CREDITÓRIOS NO SETOR BANCÁRIO BRASILEIRO}

Dissertação apresentada ao Programa de PósGraduação em Administração da Faculdade de Economia, Administração e Contabilidade da Universidade de Brasília como requisito parcial para obtenção do título de Mestre em Administração.

Área de Concentração: Finanças e Métodos Quantitativos

Orientador: Prof. Dr. Ivan Ricardo Gartner 


\section{Santos, Alexandre Leite dos}

SSA237 Determinantes das cessões de direitos creditórios d no setor bancário brasileiro / Alexandre Leite dos Santos; orientador Ivan Ricardo Gartner. -- Brasilia, 2017 .

$78 \mathrm{p}$.

Dissertação (Mestrado - Mestrado em Administração) - Universidade de Brasilia, 2017.

1. Cessões de direitos creditórios. 2. Sistema Financeiro Nacional. 3. Bancos. I. Gartner, Ivan Ricardo, orient. II. Título. 


\section{DETERMINANTES DAS CESSÕES DE DIREITOS CREDITÓRIOS NO SETOR BANCÁRIO BRASILEIRO}

Dissertação apresentada ao Programa de PósGraduação em Administração da Faculdade de Economia, Administração e Contabilidade da Universidade de Brasília como requisito parcial para obtenção do título de Mestre em Administração.

Área de Concentração: Finanças e Métodos Quantitativos

\section{Banca examinadora:}

\section{Prof. Dr. Ivan Ricardo Gartner}

Programa de Pós-Graduação em Administração da Universidade de Brasília - PPGA/UnB (Presidente da Banca)

\section{Prof. Dr. José Alves Dantas}

Programa de Pós-Graduação em Ciências Contábeis da Universidade de Brasília PPGCONT/UnB

(Membro Examinador Externo)

\section{Prof. Dr. Carlos Henrique Marques da Rocha}

Programa de Pós-Graduação em Transportes da Universidade de Brasília - PPGT/UnB

(Membro Examinador Externo) 


\section{DEDICATÓRIA}

Aos meus pais, Celi e Darlenice, pelo privilégio que sempre me foi por eles assegurado de uma ótima educação desde a infância.

À minha esposa, Juliana Lea, pelo amor, amizade, companheirismo, suporte, lições, inspirações, e, sobretudo, pela paciência.

Aos meus filhos, Miguel e Teodora, pela imensa capacidade de renovarem meu ânimo nos momentos de adversidade. 


\section{AGRADECIMENTOS}

Ao Banco Central do Brasil, por patrocinar o treinamento que culminou neste trabalho.

Ao professor Dr. Ivan Ricardo Gartner, pelo exemplo de profissionalismo desde o primeiro dia do curso, pelo apontamento das falhas, pelo direcionamento nas correções necessárias, pelo incentivo à produção científica, enfim, por toda orientação na trilha de desenvolvimento acadêmico ao longo do mestrado.

Aos professores do Programa de Pós-Graduação em Economia, Prof. Dr. Daniel Oliveira Cajueiro, e do Programa de Pós-Graduação em Contabilidade, Prof. Dr. José Alves Dantas, pela avaliação do projeto desta pesquisa e pelos conselhos, ensinamentos e direcionamentos na sessão de qualificação.

Aos colegas do Banco Central do Brasil que se fizeram presentes ao longo do trabalho. Em especial, aos amigos Eduardo Andrade Lima Vidal de Araújo, Tiago Filizzola Horta e Fabiano de Oliveira Silva, pela ajuda na melhor compreensão do tema e dos dados utilizados nesta pesquisa.

Aos colegas de curso, sobretudo aos integrantes do Grupo de Pesquisa "Mensuração e Gestão de Risco em Finanças Corporativas" Daniel Tavares de Castro, Giovanni Pacelli Carvalho Lustosa da Costa, João Gabriel de Moraes Souza, Paulo Sérgio Rosa e Raphael Leon Peres Brocchi, pelos exemplos de conduta, críticas e sugestões sempre construtivas.

A toda a equipe do PPGA, incluindo os coordenadores, docentes e funcionários da secretaria, pelo trabalho em prol de um programa de pós-graduação de excelência.

Muito obrigado! 
Esse tipo de operação, tecnicamente chamada 'cessão de crédito', representava a segunda maior fonte de captação de recursos do banco e era a mais rentável das operações de crédito. Pela sua relevância, diz o $\mathrm{BC}$, essas operações deveriam ter sido avaliadas com mais atenção.

Friedlander, D. \& Macedo, F. (2011, 16 de Fevereiro). Auditor do Panamericano falhou, diz BC. O Estado de São Paulo. Disponível em: http://economia.estadao.com.br/noticias/negocios, audi tor-do-panamericano-falhou-diz-bc, $55385 \mathrm{e}$

Questionado sobre a operação, classificada por Mantega como uma "pedalada", o Tesouro Nacional preferiu não se pronunciar.

Alves, M. R. \& Fernandes, A. (2014, 5 de Novembro). Caixa repassa $\mathrm{R} \$ 5$ bilhões em créditos 'podres'. O Estado de São Paulo. Disponível em: http://economia.estadao.com.br/noticias/geral,caixarepassa-r-5-bilhoes-em-creditos-podres-imp-, 1588098

Em nota, o banco afirmou que a cessão de carteiras "não performadas ou de baixa possibilidade de recuperação" é uma boa prática de gestão bancária utilizada por bancos no Brasil e no mundo.

Alves, M. R. (2016, 7 de abril). Para limpar balanço, Caixa repassa $\mathrm{R} \$ 23$ bilhões em 'créditos podres'. $O$

Estado de São Paulo. Disponível em: http://economia.estadao.com.br/noticias/geral,para-

limpar-balanco--caixa-repassa-r-23-bilhoes-emcreditos-podres, 10000025257 


\section{RESUMO}

As cessões de direitos creditórios consistem, basicamente, em contratos por meio dos quais um banco qualquer vende a um terceiro uma fração ou todo o direito ao fluxo de caixa proveniente de uma determinada operação de crédito. Embora os montantes financeiros movimentados com as cessões ainda sejam pouco expressivos no cenário bancário brasileiro, tais operações estiveram no centro de acontecimentos que geraram grande ruído no mercado nacional, tais como a quebra, em 2011, do Banco Panamericano S.A., e resultaram em significativos investimentos da indústria em infraestruturas específicas de controle, a exemplo da criação da Câmara de Cessões de Crédito (C3). O objetivo desta pesquisa é identificar, empiricamente, os fatores determinantes para a realização das cessões de direitos creditórios pelos bancos brasileiros, tanto por parte das instituições cedentes, ou seja, as vendedoras de operações de crédito, quanto de suas contrapartes, os bancos cessionários. Pesquisas anteriores, sejam as de cunho puramente teórico ou as de investigação empírica com foco em mercados estrangeiros, elencam variados fatores em potencial. Nesta pesquisa, testam-se aqueles que se mostraram mais relevantes em tais estudos, quais sejam: a busca dos bancos por fontes alternativas de financiamento e de provimento de liquidez, a realização de cessões visando maior diversificação de atividade e rentabilidade, o uso das cessões para fins de gestão de risco das instituições bancárias e, por fim, o aproveitamento de possíveis oportunidades de arbitragem de capital regulatório. Utiliza-se uma base de dados composta exclusivamente por informações publicadas pelo Banco Central do Brasil, elaboradas, por sua vez, com base em contas do Plano Contábil das Instituições do Sistema Financeiro Nacional (COSIF), cobrindo uma amostra de 194 bancos, no período compreendido entre o primeiro trimestre de 2008 e o segundo trimestre de 2016. São estimados modelos de regressão com variáveis dependentes limitadas, conforme suas especificações para dados em painel: o modelo logit, para identificação dos fatores que influem na probabilidade de os bancos decidirem pela realização de operações de cessão, e o modelo tobit, a fim de identificar, entre os cedentes e cessionários, a influência dos determinantes na magnitude das receitas e despesas incorridas com as cessões em relação aos totais de receitas e despesas de intermediação financeira, visando apurar o impacto das operações sobre o resultado de intermediação financeira dos bancos. Os achados da pesquisa apontam para uma maior prevalência de fatores relacionados às alternativas de financiamento e à gestão de risco dos bancos, em detrimento do possível uso das cessões para fins de diversificação, rentabilidade ou arbitragem de capital regulatório.

Palavras-chave: Cessões de direitos creditórios; Bancos; Sistema Financeiro Nacional; Logit; Tobit. 


\begin{abstract}
Loan sales consist essentially of contracts whereby any bank can sell to a third party a fraction or all the rights to the cash flows from a given credit operation. Although the financial amounts involved in these transactions are still not very significant in the Brazilian banking scenario, these operations were at the center of events that generated great noise in the domestic market, such as the bankruptcy, in 2011 of Banco Panamericano Inc., and resulted in significant investments by the banking industry in controlling infrastructures, such as the creation of the Loan Sales Chamber (C3). The objective of this research is to identify, empirically, the determining factors for the loan sales agreements conducted by Brazilian banks, including both perspectives, the transferor institutions', i.e. the sellers of credit operations, and their counterparts', the transferee banks. Previous research, whether purely theoretical or empirical research focusing on foreign markets, lists a number of potential factors. In this research, we test those that have been pointed out in such studies to be the most relevant, being: the search for alternative funding and liquidity sources, greater diversification of activities, as it relates to greater profitability, risk management and regulatory capital arbitrage. A database composed exclusively of information published by the Central Bank of Brazil, based on National Financial System Institutions Accounting Plan (COSIF) accounts, is used, covering a sample of 194 banks in the period between the first quarter of 2008 and the second quarter of 2016. Regression models with limited dependent variables are estimated according to their specifications for panel data: a logit model, to identify the factors that influence the probability of banks deciding to perform loan sales, and a tobit model, in order to identify, considering both, sellers and buyers, which determinants have influence on the magnitude of the revenues and expenses incurred with loan sales in relation to total financial intermediation revenues and expenses, in order to determine the impact of those operations on the banks' financial intermediation result. Research findings point out to a higher prevalence of factors related to banks' funding alternatives and risk management, to the detriment of the possible use of loan sales aiming at greater diversification, profitability or regulatory capital arbitrage.
\end{abstract}

Keywords: Loan Sales; Banks; National Financial System; Logit; Tobit. 


\section{LISTA DE QUADROS}

Quadro 1 - Apuração de resultado contábil nas operações de cessão de direitos creditórios conforme a Resolução CMN no 3.533, de 2008

Quadro 2-Variáveis utilizadas na pesquisa .50 


\section{LISTA DE TABELAS}

Tabela 1 - Cessões de crédito mensais realizadas na CIP-C3 de setembro de 2015 a 2016.24

Tabela 2 - Estatística Descritiva das Variáveis da Pesquisa ...............................................52

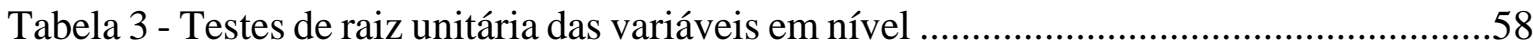

Tabela 4 - Testes de raiz unitária das variáveis Dep/AT e PL/AT após primeira diferença .59

Tabela 5 - Resultados do Logit referente às vendas de direitos creditórios ...........................59

Tabela 6 - Resultados do Logit referente às compras de direitos creditórios .........................62

Tabela 7 - Resultados do Tobit referente às receitas com cessão de direitos creditórios .......65

Tabela 8 - Resultados do Tobit referente às despesas com aquisição de direitos creditórios .69 


\section{LISTA DE ABREVIATURAS E SIGLAS}

BCB - Banco Central do Brasil

BCBS - Comitê de Supervisão Bancária da Basileia (Basel Committee on Banking Supervision)

BIS - Banco de Compensações Internacionais (Bank for International Settlements)

C3 - Câmara de Cessões de Crédito

CIP - Câmara Interbancária de Pagamentos

CMN - Conselho Monetário Nacional

COSIF - Plano Contábil das Instituições do Sistema Financeiro Nacional

Febraban - Federação Brasileira de Bancos

FIDC - Fundo de Investimento em Direitos Creditórios

FGC - Fundo Garantidor de Créditos

IAS - Norma Internacional de Contabilidade (International Accounting Standard)

IASB - Conselho de Normas Internacionais de Contabilidade (International Accounting Standards Board)

IB - Índice de Basileia

ROA - Return on Assets (Retorno sobre os Ativos)

ROE - Return on Equity (Retorno sobre o Patrimônio Líquido)

SFN - Sistema Financeiro Nacional 


\section{SUMÁRIO}

1. INTRODUÇÃ

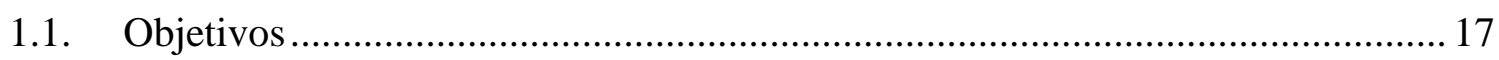

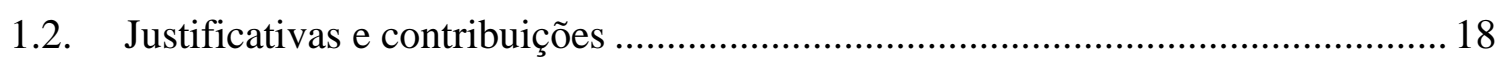

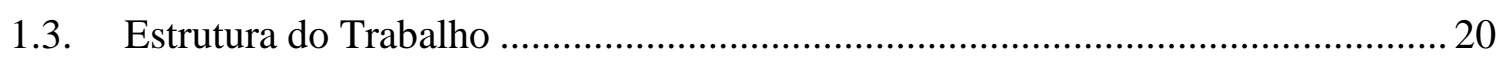

2. O MERCADO DE CESSÕES DE DIREITOS CREDITÓRIOS NO BRASIL ........... 21

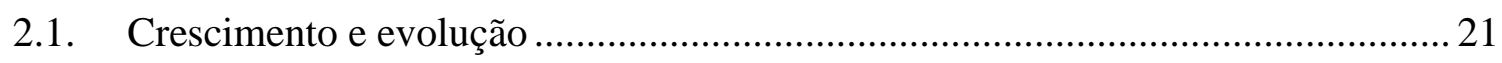

2.2. Introdução das cessões no escopo regulatório do SFN ………............................. 25

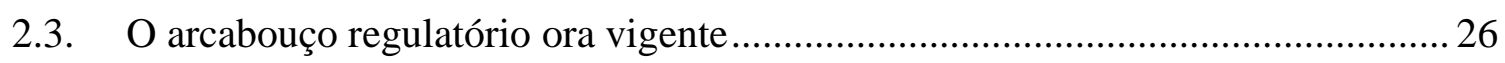

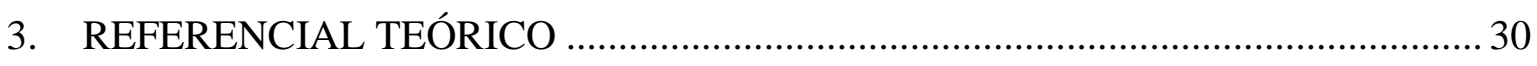

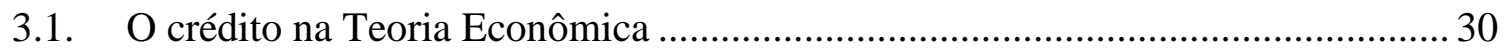

3.2. Assimetria de informações nos mercados de crédito.......................................... 32

3.3. Teoria clássica sobre cessão de direitos creditórios............................................. 35

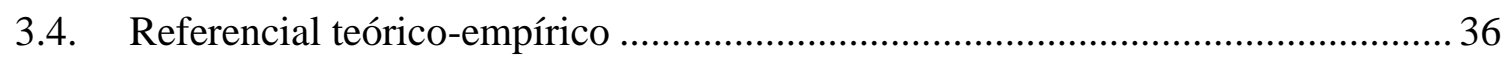

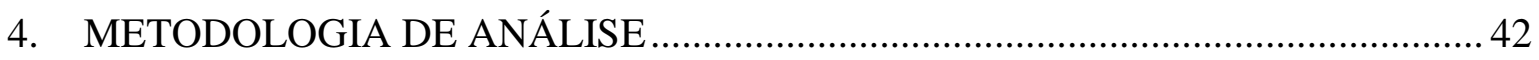

4.1. Fonte de dados, população e plano amostral ....................................................... 42

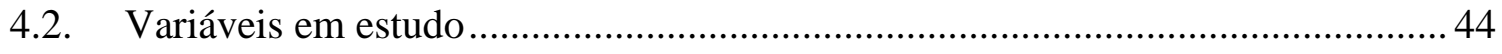

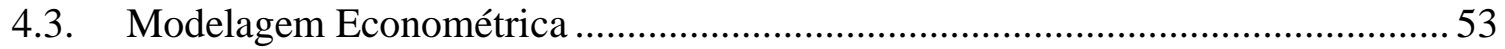

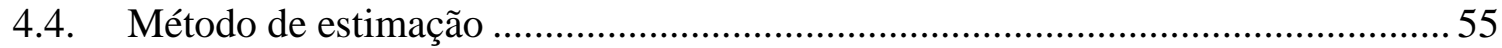

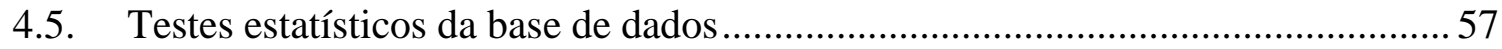

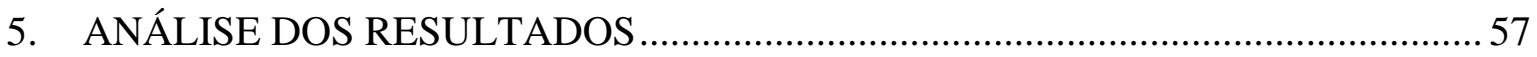

5.1. Testes de estacionariedade da base de dados ..................................................... 57

5.2. Os determinantes das vendas de direitos creditórios .............................................59

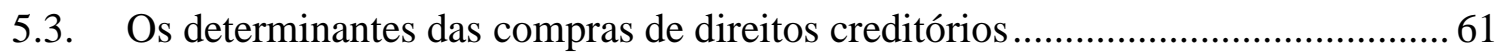

5.4. O impacto das cessões sobre as receitas de intermediação financeira dos bancos cedentes.

5.5. O impacto das cessões sobre as despesas com intermediação financeira dos

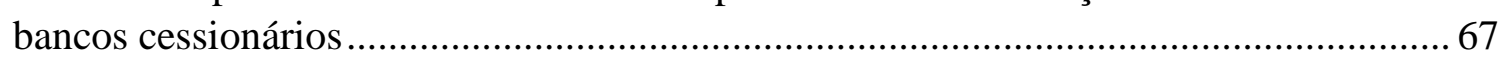

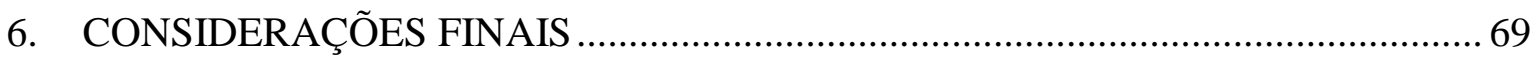

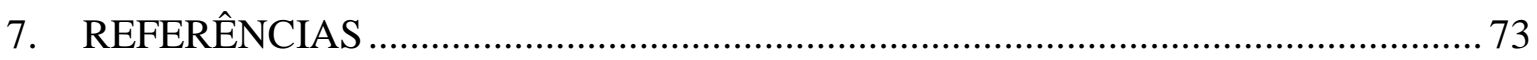




\section{INTRODUÇÃO}

Nos modernos sistemas de intermediação financeira, as operações de crédito, em especial as realizadas por instituições bancárias, não constituem apenas instrumentos de criação de poder de compra para empreendedores com necessidades imediatas de capital. Em circunstâncias específicas, contratos de crédito já celebrados podem representar, também, ativos a serem transacionados pelos agentes de mercado.

As cessões de direitos creditórios - também denominadas de forma mais genérica, na regulamentação bancária nacional, operações de venda ou transferência de ativos financeiros (CMN, 2008) -, consistem em contratos por meio dos quais um banco qualquer vende a um terceiro uma fração ou todo o direito ao fluxo de caixa proveniente de uma determinada operação de crédito (Gorton \& Pennacchi, 1995, p. 391).

A partir de tal definição, é imediata a percepção de como os fluxos agregados de cessões de direitos creditórios guardam relação direta com os estoques de operações de crédito ativas, sejam esses estoques mantidos por uma única instituição ou por todo o sistema financeiro. Quanto maior o volume de operações de crédito, em princípio, maiores as possibilidades de constituição e desenvolvimento de um mercado secundário para tais ativos.

Aos vendedores de direitos creditórios dá-se o nome de cedentes. Do outro lado da relação contratual, figuram os compradores, denominados cessionários. Quanto às diferentes modalidades de transação, as cessões se distinguem, basicamente, pelo grau de transferência ou não dos riscos e benefícios subjacentes às operações de crédito, de forma a serem classificadas em a) operações com transferência substancial dos riscos e benefícios, b) operações com retenção substancial dos riscos e benefícios e c) operações sem transferência nem retenção substancial dos riscos e benefícios (CMN, 2008).

Operações de crédito ativas podem ser negociadas com diferentes objetivos. É possível que se busque apenas um mecanismo de gerenciamento da carteira de créditos no âmbito de instituições financeiras envolvidas em atividades de intermediação financeira ou, ainda, que a transferência de ativos se dê com vistas à composição de portfolios apartados do balanço dos bancos, a serem posteriormente utilizados na estruturação de outros tipos de operação no âmbito do mercado de capitais, como é o caso das securitizações. Estas consistem em um mecanismo de lançamento de títulos, no mercado de capitais, em que se faz imprescindível a prévia formação de uma carteira de ativos destinada exclusivamente à composição de lastro para a operação. Tal carteira, por sua vez, é formada por meio da cessão de operações de 
crédito cedidas pelas instituições originadoras (Cardone-Riportella, Samaniego-Medina \& Trujillo-Ponce 2010, p. 2639).

Dessa forma, percebe-se que, no que concerne às partes potencialmente envolvidas em operações de cessão de direitos creditórios, ainda que as instituições bancárias comumente figurem entre os cedentes, é possível, em contrapartida, que, entre os cessionários, figurem também instituições não bancárias, tais como os Fundos de Investimento em Direitos Creditórios (FIDCs). Destacar tal fato se faz importante para a compreensão das diferenças entre os níveis de oferta e de demanda por cessões quando se tem como intuito analisar a participação apenas dos bancos dentro do mercado secundário de créditos.

Identificada, portanto, a prática de os bancos transacionarem, em mercados secundários, parcela significativa de seus ativos relacionados à atividade básica de intermediação, faz-se importante compreender a relevância de tais operações no que tange à gestão das instituições envolvidas. Para tanto, uma avaliação tanto das motivações quanto das implicações das cessões de direitos creditórios pressupõe o prévio conhecimento dos benefícios econômico-financeiros esperados. Um melhor entendimento quanto às expectativas de retornos financeiros e quanto aos riscos incorridos na realização de tais operações pode impactar a tomada de decisões não apenas das próprias instituições bancárias, como também de seus investidores, credores e reguladores.

De uma perspectiva teórica, oportunidades específicas de negócio, pressões do mercado, exigências regulatórias, mudanças institucionais e de tecnologias de informação são alguns dos fatores que podem influenciar diretamente na criação da oferta e da demanda por operações de crédito em um mercado secundário (Haubrich \& Thomson, 1996, p. 137).

Nesse sentido, algumas questões permeiam a maior parte dos trabalhos já realizados sobre as cessões de direitos creditórios na literatura acadêmica de finanças, sendo possível segmentá-la em alguns eixos principais. Em geral, as pesquisas buscam responder por que o mercado secundário de crédito existe, ou seja, o que determina a oferta e a demanda por direitos creditórios pelos bancos (Pavel \& Phillis, 1987; Pennacchi, 1988; Carlstrom \& Samolyk, 1995; Farruggio \& Uhde, 2015; Han, Park \& Pennacchi, 2015), como os negociantes superam problemas de assimetria informacional de forma a viabilizar o mercado de cessões (Parlour \& Plantin, 2008; Altman, Gande \& Saunders; 2010) e, mais especificamente, quais os impactos das cessões no que concerne à gestão das carteiras de crédito dos bancos, sobretudo da perspectiva de risco (Haubrich \& Thomson, 1996; Dahiya, Puri \& Saunders, 2003; Drucker \& Puri, 2009; Bedendo \& Bruno, 2012). 
Voltando-se, por outro lado, à produção nacional, encontram-se sobretudo trabalhos que, focando alguns dos aspectos teóricos previamente apontados nas pesquisas estrangeiras, buscaram contextualizar as cessões de direitos creditórios no mercado brasileiro. Nessa linha, foram avaliados, empiricamente, possíveis relações entre as operações de cessão de direitos creditórios e restrições de capital (Ribeiro \& Schiozer, 2014), bem como o uso das cessões de direitos creditórios para a gestão do risco da carteira de crédito dos bancos (Laureano, 2009).

Sob o primeiro aspecto, considerando-se a restrição de fundos para o financiamento de novas operações de crédito, manter empréstimos em carteira até o vencimento representa um custo de oportunidade, caso os bancos identifiquem alternativas de negócio mais lucrativas. Por meio da cessão de créditos, os bancos podem reaver recursos antecipadamente e realocá-los de forma mais vantajosa, seja em outros empréstimos ou em outros projetos de investimento (Ahn \& Breton, 2014, p. 196).

Quanto ao risco, medidas de qualidade creditícia da carteira cedida podem oferecer informações importantes para avaliação da participação dos bancos no mercado de cessão. A possibilidade de transferência da totalidade dos riscos envolvidos em operações de crédito e as assimetrias informacionais entre as partes envolvidas na negociação interferem diretamente na própria viabilidade de constituição desse mercado. Tais fatores representam considerável incentivo para que cessionários busquem evitar cedentes cuja carteira seja de qualidade desconhecida ou sabidamente ruim (Demsetz, 2000, pg. 205).

Há um número maior de fatores, entretanto, potencialmente influentes tanto sobre a decisão de realização das cessões de direitos creditórios quanto na determinação dos montantes envolvidos em tais operações. Para os bancos, a possibilidade de manipularem a composição da carteira de crédito por meio de negociações no mercado secundário representa, também, oportunidade de arbitragem de capital regulatório (Pavel \& Phillis, 1987; Cardone-Riportella, Samaniego-Medina \& Trujillo-Ponce 2010; Farruggio \& Uhde, 2015), de diversificação de atividades e de aumento de rentabilidade (Bannier \& Hänsel, 2008; Affinito \& Tagliaferri, 2010; Casu, Clare, Sarkysian \& Thomas, 2013), bem como de planejamento tributário (Han, Park \& Pennacchi, 2015).

A presente pesquisa se insere nesse campo da literatura que visa contribuir com uma melhor compreensão das motivações econômico-financeiras para o engajamento dos bancos no mercado secundário de créditos, não obstante ter-se como foco de análise, mais 
especificamente, a relevância e o potencial de desenvolvimento das cessões de direitos creditórios no mercado brasileiro.

Considerando, portanto, o apontamento de uma gama de motivadores para a negociação de operações de crédito no mercado secundário, e a prévia verificação, na literatura, de certa prevalência dos incentivos concernentes às alternativas de financiamento e liquidez para as operações bancárias, à diversificação e rentabilidade das instituições, à arbitragem de capital regulatório e à gestão de riscos, este trabalho busca resposta para a seguinte questão de pesquisa: quais são os determinantes da atuação das instituições bancárias brasileiras no mercado de cessões de direitos creditórios?

\subsection{Objetivos}

Uma vez estabelecidos o tema de investigação e a questão de pesquisa, tem-se como o objetivo principal deste trabalho identificar os determinantes para a decisão de os bancos nacionais adentrarem o mercado das cessões de direitos creditórios, captando, de forma segregada, os fatores mais relevantes para a atuação das instituições como cedentes e como cessionárias, por meio de teste empírico dos principais motivadores apontados na literatura de finanças.

Cabe acrescentar que, uma vez definida a participação no mercado de cessões de crédito, aos bancos impõe-se, ainda, uma segunda decisão: quais os montantes a serem negociados. Todavia, talvez tão relevante quanto conhecer tais montantes para mensuração do tamanho do mercado nacional de cessões de direitos creditórios seja avaliar o resultado financeiro dessas operações para as instituições envolvidas. Dessa forma, objetiva-se também, neste trabalho, investigar, dentre os possíveis determinantes das cessões, aqueles que indicam qual a propensão de os bancos auferirem maiores receitas com as vendas ou maiores despesas com as compras de direitos creditórios em relação ao resultado total de intermediação financeira.

Com vistas à consecução dessas tarefas, foram então estabelecidos os seguintes objetivos específicos:

- Realizar levantamento da regulamentação nacional concernente ao tema, com o intuito de verificar eventuais redirecionamentos ou distorções de incentivos provocados pelos órgãos reguladores e supervisores em relação ao esperado, a 
partir dos pressupostos teóricos, como determinantes econômico-financeiros das cessões de direitos creditórios;

- Traçar breve contextualização histórica da evolução do mercado de cessões de direitos creditórios no Brasil, a fim de identificar possíveis eventos específicos ao setor bancário brasileiro que possam ter impactado ou determinado diretamente períodos de expansão e retração das cessões em âmbito nacional;

- Analisar a magnitude das cessões realizadas no mercado bancário brasileiro, em termos do impacto de tais operações sobre o resultado financeiro apurado pelos bancos com atividades de intermediação financeira; e

- Verificar qual a perspectiva de evolução das cessões de direitos creditórios no setor bancário brasileiro a partir da identificação dos determinantes das operações e do perfil das instituições atuantes nesse mercado.

\subsection{Justificativas e contribuições}

Embora o volume de cessões de direitos creditórios no Brasil tenha apresentado forte crescimento sobretudo na primeira década dos anos 2000, com um aumento de quase 20 vezes entre 2004 e 2009 (Ribeiro \& Schiozer, 2014, p. 522), motivado investimentos significativos da indústria bancária em infraestruturas de controle e monitoramento de tais operações em decorrência de casos de fraude (Ferreira \& Lustosa, 2012, p. 24), e tenha se caracterizado mais recentemente por relevante contribuição de operações realizadas por bancos públicos (BCB, 2015, p. 23), pouco foi explorado até então na literatura acadêmica nacional quanto aos motivadores para a existência e quanto à importância de mercados secundários de crédito para a atividade das instituições bancárias.

O presente trabalho visa contribuir com a literatura nacional discutindo os fundamentos econômicos da cessão de direitos creditórios, delimitado por um contexto normativo e contábil diferenciado daqueles dos trabalhos anteriores.

Embora diversas pesquisas empíricas já tenham testado tanto em outros países quanto em âmbito local os pressupostos teóricos acerca das cessões de crédito, a regulamentação nacional ora vigente, refletindo padrões contábeis internacionais, faz uma distinção dessas operações em modalidades de uma forma que nem sempre é explorada na literatura: operações com transferência substancial dos riscos e benefícios, operações com retenção 
substancial dos riscos e benefícios, e operações sem transferência nem retenção substancial dos riscos e benefícios (CMN, 2008).

A distinção das operações de cessão de direitos creditórios, conforme a regulamentação nacional, nas modalidades sem transferência de riscos e benefícios e com transferência de riscos e benefícios introduz fatores que influem diretamente na forma de apuração de resultado conforme o grau de risco das operações, afetando os incentivos para as partes envolvidas em cada caso, e merecendo, portanto, análises específicas. Dessa forma, os benefícios econômico-financeiros esperados, e, por consequência, os possíveis motivadores das cessões de crédito realizadas pelos bancos, podem variar, a depender do tipo de cessão realizada.

Enquanto as primeiras podem ser entendidas como operações de captação com lastro em operações de crédito, haja vista a instituição cedente comprometer-se a arcar com os riscos de eventual inadimplência das parcelas de crédito cedidas, ou comprando cotas subordinadas de Fundos de Investimento em Direitos Creditórios (FIDCs), nas últimas a cedente não retém quaisquer riscos em relação às operações, configurando-se, de fato, uma venda completa e definitiva dos ativos.

Tal diferenciação impacta diretamente os incentivos e as consequências para os bancos empreenderem um ou outro tipo de cessão, e isso se reflete na forma como as operações são contabilizadas, especificamente no que diz respeito na forma e no momento de reconhecimento de resultado.

Nesse sentido, cabe destacar que a literatura nacional já produzida com esse mesmo intuito é composta, sobretudo, por trabalhos cujas análises empíricas fizeram uso de dados contabilizados conforme regulamentação anterior à do ano de 2008. Todavia, a partir daquele ano, a forma de contabilização das operações de cessão de crédito foi alterada de forma significativa por força de regulamentação do Conselho Monetário Nacional, com o intuito de que as diferentes modalidades de cessão passassem a ser registradas de forma mais fidedigna à essência econômica das operações, melhor refletindo a retenção ou transferência dos riscos e benefícios obtidos por ambos, cedentes e cessionários, e alinhando as normas contábeis nacionais às melhores práticas internacionais.

Dessa forma, busca-se como primeira contribuição desta pesquisa a utilização de base de dados que reflita de forma mais adequada os fundamentos econômico-financeiros que embasam as distintas modalidades de cessão conforme concebidas na regulamentação nacional, permitindo, portanto, análise econométrica mais apurada de como e com quais 
finalidades as instituições bancárias têm atuado nesse mercado frente às perspectivas teóricas já apontadas e exploradas em outros estudos.

Ademais, os trabalhos anteriores utilizam metodologias em que, basicamente, se regride o fluxo de cessões de direitos creditórios sobre uma série de características individuais das instituições para explicar quais os motivos mais relevantes para a atuação dos bancos nesse mercado na posição de cedentes. As análises resultantes, portanto, têm a limitação de desconsiderar as possíveis diferenças no que concerne aos incentivos para a atuação dos bancos no lado demandante do mercado, ou seja, como cessionários.

Ressalte-se, também, não se ter esgotado, na literatura nacional, a análise dos diferentes possíveis motivadores para as cessões de crédito no mercado brasileiro. Embora já se tenha investigado a relação das cessões de direitos creditórios com a gestão de risco dos bancos (Laureano, 2009) e com restrições de capital (Ribeiro \& Schiozer, 2014), tais análises não exaurem os determinantes, tampouco as variáveis passíveis de verificação nesse contexto. O presente trabalho inclui na análise outros possíveis motivadores das cessões cuja relevância, a princípio, não pode ser descartada sem maior reflexão.

Ainda considerando possíveis contribuições do trabalho, cabe mencionar, por oportuno, que a pesquisa não se reveste de utilidade apenas para o meio acadêmico, mas também para a atividade dos órgãos reguladores do setor financeiro, mais especificamente, para o Banco Central do Brasil (BCB), haja vista as operações aqui investigadas serem objeto de normatização e constante monitoramento por parte do órgão supervisor do sistema bancário nacional, e também para os próprios formuladores de políticas de gerenciamento de crédito dentro das instituições objeto do estudo: os bancos.

\subsection{Estrutura do Trabalho}

Estabelecida a contextualização inicial do objeto da pesquisa, o detalhamento dos objetivos e a apresentação das justificativas, o restante desta dissertação está estruturado da seguinte forma: em seguida, apresenta-se a evolução e o estágio atual do mercado de cessões de direitos creditórios no Brasil, bem como a regulamentação nacional correlata ao tema. Em seguida, faz-se uma revisão do referencial teórico e teórico-empírico. Posteriormente, são relatados os procedimentos metodológicos: a coleta de dados para a pesquisa, o plano amostral, os modelos estimados e métodos aplicados. Por fim, são discutidos os resultados 
e tecidas as considerações finais, tratando-se tanto das conclusões do estudo quanto de possíveis desdobramentos visando pesquisas futuras.

\section{O MERCADO DE CESSÕES DE DIREITOS CREDITÓRIOS NO BRASIL}

\subsection{Crescimento e evolução}

No Brasil, as operações de cessão de crédito começaram a ser realizadas de forma mais significativa a partir do ano de 2005, logo após a intervenção extrajudicial do Banco Central do Brasil - BCB no Banco Santos S.A., decretada em 12 de novembro de 2004.

Após constatar naquele ano uma rápida deterioração da situação patrimonial do Banco Santos S.A., o BCB decidiu afastar a diretoria daquela instituição, a fim de apurar indícios de práticas irregulares por parte dos gestores. As consequências para os correntistas do banco foram drásticas. Foram-lhes impostas restrições a saques e bloqueio de recursos. Uma vez apurados um rombo de aproximadamente $\mathrm{R} \$ 2,2$ bilhões e indícios de crimes contra $\mathrm{o}$ Sistema Financeiro Nacional (SFN) nas contas do Banco Santos S.A., o BCB decretou a liquidação extrajudicial daquela instituição em 4 de maio de 2005 (BCB, 2005).

A quebra do Banco Santos S.A. teve efeitos negativos não somente para a instituição e seus correntistas, mas para todo o segmento de bancos de pequeno e médio porte no Brasil, pois o caso gerou desconfiança generalizada quanto às práticas de gestão do setor. Houve enxugamento nas linhas de financiamento então disponíveis no mercado e o resultado foi uma forte crise de liquidez.

Nesse contexto, as cessões de carteiras de crédito passaram a representar importante fonte de financiamento para os bancos de menor porte, dado que os depósitos se tornaram uma alternativa mais restrita para a captação de recursos.

Um segundo momento de maior destaque para o mercado de cessões de direitos creditórios no Brasil se deu no ano de 2009. Em dezembro de 2008, o Conselho Monetário Nacional autorizou o Fundo Garantidor de Créditos (FGC) a elevar o limite de aplicação de recursos na compra de direitos creditórios de instituições financeiras, a fim de recompor a liquidez de bancos em dificuldades para a continuidade de suas operações (BCB, 2009, p. 43). 
Para exata compreensão desse movimento de incentivo ao mercado de cessões pelo CMN, faz-se importante contextualizar os acontecimentos da época não somente no setor bancário brasileiro, mas nos mercados financeiros internacionais, em uma perspectiva mais ampla, tendo em vista a crise originada pouco antes, nos Estados Unidos, no âmbito do mercado de títulos lastreados por hipotecas subprime daquele país.

Recessões exercem um efeito negativo sobre o mercado de cessões à medida em que reduzem a demanda por empréstimos bancários, o que, por sua vez, reduz a oferta de operações em carteira disponíveis para venda (Haubrich \& Thomson, 1996, pg. 155). A crise deflagrada em 2009 teve origem justamente na intensificação da participação dos bancos norte-americanos em um modelo de concessão de crédito denominado pela literatura “originar para distribuir" (originate-to-distribute). A alta demanda por novas hipotecas, principal ativo lastro para as operações de securitização no momento de maior aquecimento desse mercado nos EUA no período pré-crise, incentivou os bancos a buscarem maior velocidade e volume na geração desses ativos. Todavia, o atendimento à alta demanda naquele momento se deu às custas da qualidade das análises creditícias necessárias para a aferição da real capacidade de pagamento dos tomadores (Berndt \& Gupta, 2009, p. 726; Purnanandam, 2011, p. 1883).

Um repentino aumento dos níveis de inadimplência nas hipotecas subprime e os consequentes impactos negativos para instituições com ampla participação no mercado de securitização com títulos lastreados em tais ativos levou à quebra de algumas das maiores instituições financeiras dos EUA.

Com a forte instabilidade gerada a partir de então internacionalmente, os efeitos negativos foram sentidos no Brasil e uma nova crise de liquidez se instalou no mercado nacional. Um aumento do custo de acesso às fontes de captação mais uma vez impactou negativamente as alternativas de financiamento para os bancos de menor porte no Brasil. Nesse contexto, mais do que uma estratégia de negócios, a venda de carteiras se tornou uma necessidade para tais instituições, refletida no aumento do número de cessões, tanto para o Fundo Garantidor de Créditos (FGC) quanto para outros bancos e entidades securitizadoras, a fim de assegurarem a continuidade das operações dos originadores dos créditos (BCB, 2009, p. 43).

Esse segundo período de relativa expansão do mercado de cessões de direitos creditórios, entretanto, foi logo seguido de um declínio ao longo do ano de 2011. Em novembro de 2010, descobriu-se esquema de fraude contábil no Banco Panamericano S.A., 
efetivado por meio de registros deliberadamente incorretos das operações de cessão de direitos creditórios realizadas por aquela instituição.

A fim de elevar artificialmente o resultado contábil, o Banco Panamericano S.A. passou a vender os mesmos ativos para contrapartes distintas, tanto para outros bancos quanto para Fundos de Investimento em Direitos Creditórios (FIDCs), procedendo à contabilização das operações de cessão em duplicidade. Uma vez detectada tal fraude pelo $\mathrm{BCB}$, fez-se necessária, para o saneamento do desequilíbrio patrimonial do Banco Panamericano S.A., a concessão de empréstimo no valor de R \$ 2,5 bilhões pelo Fundo Garantidor de Créditos (FGC) ao grupo controlador do banco (Ferreira \& Lustosa, 2012, p. $18)$.

Tal esquema só foi possível pois, à época, os cessionários não dispunham de mecanismos que lhes permitissem verificar se os ativos sendo comprados de fato ainda pertenciam ao cedente e não haviam sido anteriormente comprometidos em outras operações (Peleias, Andrade, Alencar \& Weffort, 2012, p. 120). A revelação de fragilidades no monitoramento e controle dos ativos negociados por meio de cessão acabou por abalar momentaneamente a credibilidade de todas as instituições envolvidas nesse mercado, causando um arrefecimento da expansão das operações.

Não obstante, foi forte a reação da indústria bancária, que rapidamente empreendeu as mudanças necessárias na operacionalização das cessões de direitos creditórios a fim de assegurar que elas pudessem continuar sendo realizadas, porém, de forma mais segura.

A resposta do setor veio na forma de um maior monitoramento dos ativos negociados e de um controle mais rígido dos registros de operações de cessões de direitos creditórios. Para tanto, foram realizados investimentos em um amplo sistema centralizador das informações referentes a toda e qualquer operação de cessão realizada em âmbito nacional. Ainda em 2011, a Câmara Interbancária de Pagamentos (CIP), sociedade civil sem fins lucrativos, ligada à Federação Brasileira de Bancos (Febraban) e integrante do Sistema de Pagamentos Brasileiro (SPB), concebeu e deu início à operação de uma nova Câmara de Custódia e de Liquidação de Ativos (BCB, 2012a, p. 44).

Intitulada Câmara de Cessões de Crédito (C3), a referida câmara teve seu funcionamento oficialmente autorizado pelo Banco Central do Brasil, para início regular das operações a partir de 30 de janeiro de 2012. Ademais, a câmara foi, de imediato, incluída por aquele órgão supervisor no rol de infraestruturas do SPB classificadas como sistemicamente importantes (BCB, 2012b). A partir de então, a C3 passou a centralizar 
informações de todas as cessões de direitos creditórios realizadas no âmbito do Sistema Financeiro Nacional (SFN).

Tem-se como principal finalidade dos registros realizados na $\mathrm{C} 3$ a redução das assimetrias informacionais entre os negociantes que permitiram casos como os dos bancos Santos S.A. e Panamericano S.A., promovendo-se transparência quanto à propriedade e utilização de créditos em operações de cessão, e buscando-se evitar a duplicidade de cessões ou de uso dos ativos negociados na forma de garantias prestadas em outras operações.

Dessa forma, desde então, para que qualquer banco negocie contratos ou parcelas de crédito no âmbito do SFN, é obrigatório que, primeiramente, proceda ao registro da operação na C3. Atualmente, dos 82 participantes da C3, 56 são bancos.

Apesar do início oficial das operações no início de 2012, a série de estatísticas mensais disponibilizada publicamente pela C3 tem início apenas em setembro de 2015. O curto período não permite qualquer avaliação mais aprofundada quanto à evolução do mercado de cessões a partir do momento em que passaram a ser objeto de registro obrigatório na Câmara, mas fornece uma visão geral sobre os montantes transacionados nos anos de 2015 e 2016, pouco tempo, portanto, depois da criação da câmara:

Tabela 1 - Cessões de crédito mensais realizadas na CIP-C3 de setembro de 2015 a 2016.

\begin{tabular}{|c|c|c|c|c|c|}
\hline Ano & Mês & Qtde Cessões (1) & Qtde Contratos (2) & Qtde Parcelas (3) & Liq. Financeira $(\mathrm{R} \$)$ \\
\hline \multirow{4}{*}{2015} & Setembro & 41 & 222.160 & 9.980 .509 & 2.887.032.827 \\
\hline & Outubro & 78 & 259.817 & 14.687 .191 & 1.364 .023 .799 \\
\hline & Novembro & 60 & 212.353 & 7.229 .430 & 1.728 .154 .561 \\
\hline & Dezembro & 78 & 425.259 & 21.958 .791 & 4.920 .933 .954 \\
\hline \multirow{9}{*}{2016} & Janeiro & 63 & 77.055 & 3.385 .695 & 1.347 .048 .214 \\
\hline & Fevereiro & 58 & 63.229 & 3.515 .102 & 622.614 .710 \\
\hline & Março & 77 & 374.816 & 21.675 .888 & 4.705 .872 .500 \\
\hline & Abril & 39 & 37.842 & 1.862 .246 & 542.122 .380 \\
\hline & Maio & 58 & 172.008 & 10.530 .494 & 1.870 .913 .553 \\
\hline & Junho & 94 & 400.436 & 22.897 .698 & 3.982 .258 .024 \\
\hline & Julho & 83 & 192.609 & 12.721 .291 & 1.241 .390 .040 \\
\hline & Agosto & 103 & 163.622 & 10.123 .557 & 1.673 .652 .626 \\
\hline & Setembro & 114 & 296.886 & 16.838 .784 & 2.419.956.557 \\
\hline
\end{tabular}

Fonte: CIP-C3 (Câmara de Cessões de Crédito). Estatísticas mensais. Acesso em outubro de 2016.

Legenda: (1) Qtde Cessões - Quantidade de operações de Cessões de Crédito efetuadas mensalmente na C3; (2) Qtde Contratos - Quantidade de Contratos de Crédito que compõem as operações de Cessões; (3) Qtde Parcelas - Quantidade mensal de parcelas que compõem os Contratos Cedidos na C3; (4) Liquidação Financeira - Somatório dos valores liquidados das operações de Cessões de Créditos realizadas na C3 
durante o mês; processo de transferência de recursos financeiros entre os Participantes (cedente / cessionário).

Fato é que, no semestre imediatamente posterior ao início de funcionamento da $\mathrm{C} 3$, houve aumento de $48 \%$ na quantidade de cessões e de $26 \%$ em termos de valor financeiro (BCB, 2013, p. 43). Ademais, para avaliação da relevância das cessões de crédito no SFN, há de se considerar, além dos fluxos financeiros, a finalidade das operações. Sendo assim, faz-se importante também analisar os principais motivos sendo apontados para a atuação dos bancos no mercado secundário de crédito. Entre eles, destaca-se hoje a importância do uso das cessões pelos bancos para fins de gestão de risco.

No primeiro semestre de 2015, operações de crédito inadimplentes foram objeto de cessão, sobretudo, pelos bancos públicos (BCB, 2015, p. 23). Em contextos de menor aquecimento do mercado de crédito, as vendas e transferências de ativos financeiros têm o condão de conter a elevação dos índices de inadimplência registrados pelos bancos cedentes, já que a cessão de créditos inadimplidos, quando realizada com transferência substancial dos riscos e benefícios, autoriza a instituição bancária, de acordo com a regulamentação em vigor, a baixar contabilmente esses ativos de seus balanços (CMN, 2008).

Dessa forma, a cessão de direitos creditórios é um artifício útil para os bancos por possibilitar-lhes, além da captação de recursos e reconhecimento de resultado, a gestão da carteira de crédito de forma a possibilitar-lhes reduções de montantes de provisionamento e de requerimentos de capital regulamentar.

\subsection{Introdução das cessões no escopo regulatório do SFN}

Ao se tratar de cessões de direitos creditórios, faz-se importante esclarecer a distinção estabelecida pela regulamentação bancária nacional entre operações realizadas com transferência substancial de riscos e benefícios e operações com retenção substancial de riscos e benefícios, haja vista o impacto dessa diferenciação em termos da contabilização das operações, da gestão do risco de crédito dos ativos financeiros transacionados e de sua influência na apuração do resultado das instituições bancárias.

O que segue, portanto, é uma breve revisão do regramento de tais operações, desde sua introdução no escopo regulatório do Conselho Monetário Nacional ao maior detalhamento na normatização e supervisão realizadas pelo Banco Central do Brasil. 
Tem-se registro de menção às operações de cessão de direitos creditórios em normativo do Conselho Monetário Nacional já na Resolução CMN nº 453, de 16 de novembro de 1977, a qual autorizou os bancos de investimento a cederem ou alienarem, a outros bancos de investimento e a bancos comerciais, créditos oriundos de operações de empréstimos destinados ao financiamento de capital fixo ou de capital de movimento (CMN, 1977).

A Resolução $n^{\circ}$ 453, de 1977, encontra-se revogada desde 1988, mas nota-se que, desde sua edição, já se fazia menção à figura da coobrigação, ou retenção de riscos da operação, observada, segundo a norma, "quando a instituição cedente se responsabilizar pela boa liquidação do crédito" (CMN, 1977).

Por sua vez, a Resolução CMN nº 1.762, de 31 de outubro de 1990, foi o primeiro normativo com foco exclusivamente no disciplinamento das operações de cessão de crédito, ampliando-se o escopo regulatório de forma a autorizar a realização de cessões por instituições financeiras e sociedades de arrendamento mercantil. Neste caso, também se consignou a existência de modalidades distintas de operação. Nos termos do normativo, diferenciava-se cessões com coobrigação - quando a instituição cedente se responsabiliza, subsidiariamente, pela liquidação dos créditos cedidos - e cessões sem coobrigação (CMN, 1990).

\subsection{O arcabouço regulatório ora vigente}

A Resolução CMN n 2.686, de 26 de janeiro de 2000, autoriza os bancos e demais instituições financeiras a cederem créditos a sociedades anônimas que tenham por objeto exclusivo a aquisição de tais ativos. Tal Resolução veda a recompra a prazo de créditos cedidos. Todavia, admite a recompra à vista, bem como a substituição dos mesmos, desde que previsto nos estatutos da cessionária (CMN, 2000). Trata-se, portanto, de normativo que pela primeira vez disciplinou no Brasil as cessões de direitos creditórios às companhias securitizadoras.

Após sucessivas revogações e edição de novos normativos visando a introdução de alterações pontuais e a consolidação de normas que abordassem o tema, chegou-se ao texto da Resolução $\mathrm{CMN}^{\circ}{ }^{\circ} 2.836$, de 30 de maio de 2001. Tal Resolução autoriza as instituições financeiras a ceder, a instituições de mesma natureza, créditos oriundos de operações de 
empréstimo, financiamento ou arrendamento mercantil, bem como títulos de crédito (CMN, 2001).

A Resolução $\mathrm{CMN} \mathrm{n}^{\circ}$ 2.836, de 2001, insere dispositivo que expressamente diferencia as operações de cessão de direitos creditórios realizadas com coobrigação das operações compromissadas, ao vedar a recompra, a prazo, de créditos vincendos anteriormente cedidos.

O mesmo normativo condiciona a cessão de créditos para instituições não integrantes do SFN à realização das operações na modalidade sem coobrigação da cedente, e impõe que a liquidação seja efetuada à vista, sendo vedada a recompra dos créditos cedidos.

Ademais, a Resolução CMN n 2.836, de 2001, veda também a hipótese de que qualquer transação posterior envolvendo os créditos objeto de cessão possa vir a acarretar retorno do risco, ainda que de forma indireta, para a cedente. Para tanto, impõe-se que a cedente inclua, no primeiro balanço publicado após a realização da operação, nota explicativa informando os valores contábil e de cessão dos créditos, bem como os reflexos patrimoniais e no resultado decorrentes da transação (CMN, 2001).

Fechando o arcabouço dos principais normativos exarados pelo Conselho Monetário Nacional visando disciplinar as cessões de direitos creditórios, tem-se a mais recente alteração regulatória de impacto na Resolução CMN nº 3.533, de 31 de janeiro de 2008, a qual “estabelece procedimentos para classificação, registro contábil e divulgação de operações de venda ou de transferência de ativos financeiros" (CMN, 2008). Cabe ressalvar que, apesar de ter entrado em vigor no início de 2008, a própria Resolução estabeleceu que só produziria efeitos a partir de $1^{\circ}$ de janeiro de 2012.

Antes da edição da Resolução $n^{\circ} 3533$, de 2008 , não se fazia distinção quanto à forma de registro contábil das operações com e sem coobrigação, isto é, inexistiam critérios específicos consubstanciados em norma a serem considerados quanto à transferência de riscos e benefícios e transferência de controle para fins de contabilização das cessões de crédito. Estas eram sempre, a despeito da essência econômica e objetivos da operação, tratadas como compras e vendas definitivas dos ativos nos registros bancários.

Dessa forma, mesmo nos casos em que não ocorria transferência de riscos e benefícios, a instituição cedente procedia, de acordo com a regulamentação em vigor, à baixa dos créditos cedidos em suas contas patrimoniais. Ambas as modalidades de operação, tanto com coobrigação quanto sem coobrigação, deviam, portanto, ter o resultado apurado e registrado contabilmente na data da negociação. De outro lado, cabia à instituição cessionária fazer, também na data da negociação, o registro da operação de crédito adquirida em seu balanço. 
Ressalte-se, entretanto, que nos casos em que se realizassem cessões com coobrigação, à cedente cabia também a responsabilidade de registrar contabilmente a coobrigação em contas no sistema de compensação que representassem a garantia prestada.

Ainda assim, nada impedia a baixa dos ativos e o reconhecimento de resultado mesmo nas operações que em nada modificavam a posição do banco em termos de risco e dos fluxos de caixa esperados, como se observa, por exemplo, nos casos de cessão de créditos para FIDCs seguida de compra de cotas subordinadas em montante suficiente para cobertura das perdas esperadas.

Dessa forma, mesmo inalterado o risco de crédito para a instituição bancária, o procedimento resultava em redução do capital regulatório exigido e na dispensa de constituição de provisão para os créditos de liquidação duvidosa, uma vez que as operações de crédito propriamente eram retiradas do balanço dos bancos.

A alteração da norma contábil teve como intuito, portanto, fazer com que os registros das operações refletissem de forma mais fidedigna a essência econômica das operações, em consonância com pronunciamento do Conselho de Normas Internacionais de Contabilidade (IASB) que trata do registro e mensuração de instrumentos financeiros (IAS 39).

Seguindo o recomendado pelo IASB, a Resolução $n^{\circ} 3.533$, de 2008, determinou a classificação das operações em três categorias, cada qual com tratamento contábil e regras de divulgação específicas, com base em critérios de transferência de riscos e benefícios e, subsidiariamente, transferência de controle:

(i) Operações com transferência substancial de riscos e benefícios;

(ii) Operações sem transferência substancial de riscos e benefícios, incluindo operações com a prestação de garantias, acordos de recompra, aquisição de cotas subordinadas de fundos ou opções de compra ou de venda;

(iii) Operações sem transferência nem retenção substancial de riscos e benefícios. Importante destacar que a norma confere às instituições financeiras a responsabilidade quanto à avaliação sobre a efetiva transferência ou retenção dos riscos e benefícios associados aos ativos financeiros transacionados, acrescentando a necessidade de que tal classificação seja feita com base em critérios consistentes e passíveis de verificação pelos supervisores bancários.

Dessa forma, a Resolução $n^{\circ} 3.533$, de 2008, estabeleceu critérios diferenciados para a baixa contábil dos ativos e reconhecimento de resultado com as operações de cessão, a depender da modalidade. 
No que concerne aos registros patrimoniais, apenas nas operações do tipo (i) e nas operações do tipo (iii) realizadas com efetiva transferência de controle, o ativo deve ser baixado, pelo cedente, do título contábil utilizado para registro da operação original. No caso das cessões do tipo (ii), a operação de crédito deve permanecer, na sua totalidade, registrada no ativo do cedente. Por fim, nas operações do tipo (iii) realizadas sem transferência de controle, o ativo deve permanecer registrado na proporção do seu envolvimento continuado, que é o valor pelo qual a instituição continua exposta às variações no valor do ativo transferido.

Já no que diz respeito ao efetivo impacto de cada uma das modalidades de cessão sobre a apuração do resultado contábil pelas instituições envolvidas, a norma estabelece que se proceda conforme o Quadro 1:

Quadro 1 - Apuração de resultado contábil nas operações de cessão de direitos creditórios conforme a Resolução no 3.533, de 2008.

\begin{tabular}{|c|c|c|}
\hline . & \multicolumn{2}{|c|}{ Efeito no Resultado } \\
\hline Modalidade de cessão & Cedente & Cessionário \\
\hline $\begin{array}{l}\text { Com transferência de } \\
\text { riscos e benefícios }\end{array}$ & $\begin{array}{l}\text { O resultado positivo ou negativo } \\
\text { apurado na negociação deve ser } \\
\text { apropriado ao resultado do período }\end{array}$ & $\begin{array}{l}\text { O ativo financeiro adquirido deve ser } \\
\text { registrado pelo valor pago, em } \\
\text { conformidade com a natureza da operação } \\
\text { original. }\end{array}$ \\
\hline $\begin{array}{l}\text { Com retenção de } \\
\text { riscos e benefícios }\end{array}$ & $\begin{array}{l}\text { As receitas e as despesas devem ser } \\
\text { apropriadas de forma segregada ao } \\
\text { resultado do período pelo prazo } \\
\text { remanescente da operação, no } \\
\text { mínimo mensalmente }\end{array}$ & $\begin{array}{l}\text { As receitas devem ser apropriadas ao } \\
\text { resultado do período, pelo prazo } \\
\text { remanescente da operação, no mínimo } \\
\text { mensalmente }\end{array}$ \\
\hline $\begin{array}{l}\text { Sem transferência } \\
\text { nem retenção de } \\
\text { riscos e benefícios, } \\
\text { mas com } \\
\text { transferência de } \\
\text { controle do ativo } \\
\text { financeiro }\end{array}$ & $\begin{array}{l}\text { O resultado positivo ou negativo } \\
\text { apurado na negociação deve ser } \\
\text { apropriado ao resultado do período. }\end{array}$ & $\begin{array}{l}\text { O ativo financeiro adquirido deve ser } \\
\text { registrado pelo valor pago, em } \\
\text { conformidade com a natureza da operação } \\
\text { original. }\end{array}$ \\
\hline $\begin{array}{l}\text { Sem transferência } \\
\text { nem retenção de } \\
\text { riscos e benefícios, e } \\
\text { sem transferência de } \\
\text { controle do ativo } \\
\text { financeiro }\end{array}$ & $\begin{array}{l}\text { O resultado positivo ou negativo } \\
\text { apurado na negociação, referente à } \\
\text { parcela cujos riscos e benefícios } \\
\text { foram transferidos, deve ser } \\
\text { apropriado proporcionalmente ao } \\
\text { resultado do período de forma } \\
\text { segregada; e as receitas e despesas } \\
\text { devem ser apropriadas de forma } \\
\text { segregada ao resultado do período, } \\
\text { pelo prazo remanescente da } \\
\text { operação, no mínimo mensalmente. }\end{array}$ & $\begin{array}{l}\text { As receitas devem ser apropriadas ao } \\
\text { resultado do período, pelo prazo } \\
\text { remanescente da operação, no mínimo } \\
\text { mensalmente. }\end{array}$ \\
\hline
\end{tabular}

Fonte: CMN (2008). 


\section{REFERENCIAL TEÓRICO}

\subsection{O crédito na Teoria Econômica}

O crédito é tema que perpassa as obras de autores inseridos em praticamente todas as escolas de pensamento da Teoria Econômica. Foge ao escopo do presente trabalho uma ampla revisão dessa literatura. Entretanto, faz-se imprescindível pontuar algumas notórias contribuições ao desenvolvimento teórico do tema, no que tange às suas origens no âmbito da Economia.

Maior expoente da Economia clássica, Smith (1996) aborda a importância da moeda e do crédito para o desenvolvimento das atividades mercantis, bem como os impactos dos empréstimos bancários sobre a acumulação de capital. Focando a atividade bancária na Europa do século XIX, Smith (1996, p. 312) analisa como o adiantamento de recursos por meio da extensão de crédito proporciona maior dinâmica à relação entre comerciantes, manufatores, arrendatários e proprietários de terra. Ademais, o autor faz menção a questões que se mostram fundamentais para a compreensão da dinâmica do crédito ainda nos dias de hoje, tais como a importância das relações de confiança em que se baseiam e as dificuldades encontradas pelos bancos para lidar com o desafio de obter simultaneamente informações precisas e regulares sobre a conduta e a situação financeira de um elevado número de clientes.

Por sua vez, ainda no âmbito da escola clássica, Ricardo (1996, p. 63) apresenta teoria segundo a qual o trabalho empregado na produção é o principal determinante do valor de uma mercadoria. Ao desenvolver tal ideia, o autor analisa o papel desempenhado por uma classe à qual se refere de forma especialmente crítica, composta por banqueiros e "homens endinheirados", não engajados em qualquer tipo de atividade produtiva e que vivem apenas dos juros de dinheiro emprestado aos setores empreendedores da sociedade. Apesar de apresentar algumas restrições com tal classe, Ricardo (1996, p. 64) reconhece que "nenhum grande industrial, por mais rico que seja, limita seus empreendimentos ao que seus próprios recursos lhe permitem", e que os empréstimos bancários, portanto, se fazem imprescindíveis quando produtores se deparam com aumentos repentinos da demanda por suas mercadorias.

Já no âmbito da Economia neoclássica, Jevons (1996), ao destacar a complexidade do tema capital e sua importância em Economia, utiliza a ideia de crédito a fim de estabelecer uma analogia com o tema central. Para Jevons (1996, p. 226), “o crédito é uma coisa abstrata 
intangível - o poder de obter empréstimos de propriedade. Do mesmo modo, o capital é o poder e a vontade de conceder empréstimos, também uma ideia abstrata intangível".

Marx, crítico dos princípios defendidos por clássicos e neoclássicos referentes à teoria do valor-trabalho, e pilar de uma das correntes de pensamento historicamente mais influentes no âmbito da Teoria Econômica, também dedicou parte de sua obra à avaliação do papel do crédito na Economia. Em sua análise das funções da moeda em circulação, especialmente no que concerne sua utilidade enquanto instrumento de trocas, Marx (1996, p. 247) afirma: "o dinheiro de crédito pressupõe relações que, do ponto de vista da circulação simples das mercadorias, ainda nos são inteiramente desconhecidas".

Todavia, dentro de sua perspectiva teórica de crítica à forma de organização dos agentes econômicos no capitalismo, Marx (1996) faz uso da essência dos conceitos de crédito e de risco de inadimplência para transmitir sua visão do que considera exploração dos trabalhadores:

\begin{abstract}
Em todos os países com modo de produção capitalista, a força de trabalho só é paga depois de ter funcionado durante o prazo previsto no contrato de compra, por exemplo, no final de cada semana. Por toda parte, portanto, o trabalhador adianta ao capitalista o valor de uso da força de trabalho; ele deixa consumi-la pelo comprador, antes de receber o pagamento de seu preço; por toda parte, portanto, o trabalhador fornece crédito ao capitalista. Que esse fornecimento de crédito não é nenhuma fantasia vã, mostra-o não só a perda ocasional do salário creditado quando ocorre bancarrota do capitalista, mas também uma série de efeitos mais duradouros (Marx, 1996, p. 291).
\end{abstract}

Reconhecido por seu trabalho no âmbito do tema desenvolvimento econômico, Schumpeter (1997, p. 83), reconhece no banqueiro tanto um intermediário quanto um produtor da mercadoria "poder de compra". Nessa visão, o crédito representa o modo como se dá a produção desse poder de compra, o qual, para Schumpeter (1997, p. 107), é primordial para a inovação industrial, para o estímulo ao empreendedorismo, e, por consequência, ao desenvolvimento econômico.

Assim como Marx, Keynes empresta seu nome a uma das mais importantes escolas de pensamento econômico. Em uma análise que dá grande destaque à importância da demanda agregada na Economia, ao papel do Estado em momentos de crise e outros temas hoje centrais especialmente para a macroeconomia, o autor analisa os impactos gerais do crédito. Para Keynes (1996, p. 107), a concessão do crédito bancário faz surgir três tendências: aumento da produção; alta no valor da produção marginal expressa em unidades de salário 
e alta da unidade de salários em termos de moeda. Tais tendências podem ter efeito sobre a distribuição da renda real.

\subsection{Assimetria de informações nos mercados de crédito}

A constatação de que os agentes econômicos buscam, em variadas situações negociais reais, auferir vantagens para si em detrimento dos interesses de suas contrapartes, levou ao desenvolvimento de estudos no âmbito da Economia acerca dos "custos econômicos da desonestidade" (Akerlof, 1970, p. 495).

Em qualquer mercado, quando vendedores de produtos de má qualidade omitem informações quanto ao real estado dos bens transacionados, visando apenas o curto prazo, é possível que consigam ludibriar os compradores. No entanto, há um efeito nocivo de tal comportamento no longo prazo. Cientes de estarem expostos a esse risco, os compradores passam a não se dispor a negociar em uma faixa de preços acima do que corresponderia apenas à média de qualidade dos produtos no mercado. Tal comportamento dos compradores acarreta um equilíbrio no nível de preços que inviabiliza a negociação para os ofertantes de produtos de maior qualidade, dada a impossibilidade de cobrirem seus custos (Akerlof, 1970, p. 491).

O resultado da assimetria informacional entre os agentes e do comportamento oportunista de parte dos vendedores é a exclusão dos produtos de mais alta qualidade do mercado (Akerlof, 1970, p. 491). Entre os variados contextos em que se pode observar essa dinâmica estão as negociações no mercado de crédito, o qual tem na assimetria informacional uma de suas características definidoras (Dell'Ariccia, 2001, p. 1958).

No que concerne à decisão inicial do negócio, ou seja, o momento da originação das operações de crédito, considerando as taxas de juros o "preço" que se cobra pelo risco incorrido em empréstimos e financiamentos, determinados emprestadores podem, por questões concorrenciais, ofertar deliberadamente taxas excessivamente baixas. Entretanto, na indisponibilidade de um nível adequado de informações para análise dos clientes atraídos pelas taxas mais baixas, é provável que, entre estes, estejam justamente os tomadores com as mais baixas capacidades de pagamento (Akerlof, 1970, p. 498).

Mas, se por um lado a falta de informações adequadas sobre os tomadores pode resultar na concessão de créditos com um maior nível de risco, por outro, a assimetria informacional 
pode até mesmo inviabilizar novas concessões, acarretando o racionamento de crédito e a contração desse mercado.

Tal situação pode ser caracterizada de duas formas: a) ainda que distintos tomadores em potencial sejam aparentemente iguais em suas capacidades de pagamento, é possível que alguns consigam tomar emprestado e outros não, independente de os clientes rejeitados estarem dispostos a pagar taxas de juros mais altas; e b) dados determinados níveis de oferta de crédito, é possível que alguns indivíduos se vejam totalmente incapazes de tomar emprestado, qualquer que seja a taxa de juros, muito embora essa situação possa se alterar em cenários de maior oferta de crédito (Stiglitz \& Weiss, 1981, p. 394).

A elevação de taxas de juros ou dos requerimentos de capital dos tomadores podem resultar na formação de uma carteira de crédito mais arriscada pelos bancos, seja por desencorajar a demanda por parte de tomadores menos arriscados, ou por induzir os tomadores a investirem em projetos de maior retorno, porém de maior risco (Stiglitz \& Weiss, 1981, p. 408).

Mas, na ausência de problemas com o tomador, uma vez estabelecida a relação entre bancos e clientes, o transcurso normal da operação por certo período de tempo resulta em vantagens informacionais aos bancos, especialmente no momento de eventuais refinanciamentos, reduzindo a competição no mercado de crédito ex-post (Sharpe, 1990).

Decorre como condição necessária à realização de operações de crédito, principalmente em se tratando das de mais longo prazo, que às instituições financeiras seja concedido acesso a fontes privadas de informações relacionadas ao tomador. Tanto no momento da análise inicial, visando o deferimento do crédito, quanto ao longo do curso da operação, os contratos de empréstimo e financiamento podem condicionar a operação ao envio periódico de relatórios financeiros ao credor. Isso significa que, uma vez concedido o crédito, os bancos têm condições de reunir, enquanto durar o relacionamento com o cliente, informações sobre a saúde financeira do tomador, capazes de mitigar em parte os problemas de assimetria informacional, em um processo de aprendizado contínuo sobre o cliente (Dell'Ariccia, 2001, p. 1957).

No entanto, os ganhos desse aprendizado são limitados e, via de regra, não extensivos a todo o mercado, pois os dados coletados pelos bancos no relacionamento com seus clientes são proprietários, isto é, de acesso apenas pela própria instituição e não observáveis diretamente por terceiros (Dell'Ariccia, 2001, p. 1958). 
É nesse sentido que o mercado secundário de créditos também, em princípio, sujeitase a problemas de seleção adversa, pois envolve negociantes que dispõem de larga vantagem, do ponto de vista informacional, em relação às suas contrapartes. No relacionamento direto com os tomadores, os bancos não só recebem informações financeiras detalhadas dos clientes como, também, se tornam capazes de registrar o histórico de cumprimento de obrigações contratuais e de requisições de refinanciamento ou rolagem de dívidas. Ademais, podem tomar conhecimento antecipadamente das projeções de desempenho financeiro com base nas estratégias de negócio dos tomadores e até mesmo de eventuais planos de fusões e aquisições. Tais informações, reitere-se, ou são inacessíveis para partes não diretamente relacionadas com o tomador, ou se tornam disponíveis com relativo atraso (WittenbergMoerman, 2008, p. 241).

Sendo assim, quando as negociações ocorrem não mais entre o banco e seu tomador, mas no mercado secundário de créditos, o maior conhecimento dos originadores frente ao dos potenciais compradores quanto à qualidade dos ativos objeto da negociação pode distorcer as decisões de investimento, caso o objetivo do vendedor seja tão-somente levantar fundos de contrapartes quase sempre menos informadas, a despeito da expectativa de desempenho futuro dos créditos (Lucas \& McDonald, 1992, p. 86).

Nesse sentido, a venda de direitos creditórios e os termos do negócio podem representar uma forma de sinalização quanto à qualidade dos ativos transacionados. A retenção de parte dos riscos e benefícios da carteira é uma forma de o banco reduzir problemas de agência, pois, nesse caso, fica claro o incentivo para que o originador se preocupe com a manutenção do valor da operação (Gorton \& Pennacchi, 1995, pg. 394).

Por outro lado, quando tal sinalização não ocorre de forma clara e há a percepção entre os compradores de uma maior exposição à seleção adversa, a própria precificação dos créditos no mercado secundário acaba por refletir a expectativa dos agentes quanto à possibilidade de estarem sendo transacionados produtos, em média, de menor qualidade (An, Deng \& Gabriel, 2011, p. 304).

Além disso, outro fator potencialmente a favor da viabilidade das negociações de créditos no mercado secundário está relacionado às relações de longo prazo entre as instituições financeiras. A preocupação com possíveis danos reputacionais decorrentes da transferência de ativos de menor qualidade creditícia sem o conhecimento do comprador pode introduzir uma tendência aos bancos venderem no mercado secundário apenas os 
créditos de menor risco, e, portanto, com menores chances de acarretarem prejuízos futuros aos compradores das operações (Albertazzi, Eramo, Gambacorta \& Salleo, 2015, p. 48).

\subsection{Teoria clássica sobre cessão de direitos creditórios}

Os primeiros trabalhos acadêmicos com foco no tema cessão de direitos creditórios datam do final da década de 1980 (Greenbaum \& Thakor, 1987; James, 1988; Pennacchi, 1988). Nesse período, a assimetria informacional entre vendedores e compradores de direitos creditórios e outros fatores que exercem influência sobre os custos de financiamento das instituições financeiras foram apontados na literatura como os principais determinantes do comportamento dos bancos no mercado secundário de crédito.

Enquanto modelos assumindo informação perfeitamente simétrica e ausência de intervenção governamental indicavam que os bancos seriam indiferentes entre financiarem suas operações por meio da captação de depósitos ou da realização de vendas de operações de crédito (Greenbaum \& Thakor, 1987, p. 386), o relaxamento de tais restrições, bem como a inclusão de outros fatores intervenientes, tais como a participação de seguradoras, indicavam haver certa variabilidade sobre qual seria a estratégia de financiamento mais adequada, a depender do cenário.

Nessa linha, buscava-se avaliar se, como, e em quais contextos a mitigação dos problemas de assimetria informacional entre instituições bancárias poderia tornar viável a utilização das operações de cessão de créditos na redução dos custos de financiamento das operações bancárias.

Antes do estudo mais aprofundado dessa questão, era disseminado o entendimento de que empréstimos bancários não constituíam ativos negociáveis, devido, sobretudo, a problemas de risco moral. Argumentava-se que, uma vez transferida por completo a exposição às perdas decorrentes de uma eventual inadimplência dos tomadores, os bancos não teriam mais quaisquer incentivos para manterem o monitoramento das operações e para continuarem efetuando análises quanto ao risco de crédito e ao desempenho financeiro das contrapartes cujas obrigações foram negociadas (Pennacchi, 1988, p. 377).

Sendo assim, para que os bancos tivessem os incentivos corretos para manter as atividades de avaliação de riscos e de monitoramento de seus empréstimos, acreditava-se ser necessária a retenção de ao menos uma parcela do risco de inadimplência relativo a tais operações, mesmo depois de cedidas (Pennacchi, 1988, p. 389). Por outro lado, a capacidade 
de um banco qualquer de vender seus direitos creditórios para terceiros dependeria da percepção dos eventuais compradores quanto à efetividade dos incentivos postos para a instituição bancária em favor dessa continuidade no monitoramento das operações cedidas (James, 1988, p. 399).

A solução para tal impasse consistiria no estabelecimento de alguma forma de contrato entre vendedores e compradores, por meio do qual a estrutura de incentivos para a repartição dos riscos poderia ser melhor delineada e assegurada. Uma vez elaborado tal contrato, se faria possível que bancos inseridos em ambientes de alta competitividade na captação de depósitos, ou sujeitos a restrições regulatórias, tais como requerimentos de reservas e de capital, reduzam seus custos de financiamento por meio das vendas de operações de crédito (Pennacchi, 1988, p. 384).

Todavia, ainda que restrições regulatórias possam motivar as vendas de créditos, há dinâmicas do próprio mercado que talvez sejam mais relevantes na indução dos bancos à realização de tais operações.

A assimetria informacional entre cedentes e cessionários levou diversas instituições a perceberem na originação e distribuição de operações de crédito uma atividade lucrativa, caso inexistente qualquer obrigatoriedade de manutenção das operações em carteira até o vencimento. Do lado da demanda, um mercado de venda e transferência de créditos permite a bancos com folga de capital adquirirem operações avaliadas como potencialmente lucrativas, originadas por bancos cuja estrutura de capital não lhes permitiria assumir riscos adicionais (Carlstrom \& Samolik, 1995, p. 637).

\subsection{Referencial teórico-empírico}

Pavel e Phillis (1987) apresentam um dos primeiros trabalhos empíricos com foco no tema de cessão de direitos creditórios. Os autores aplicaram, utilizando dados de cessões de crédito realizadas no sistema bancário norte-americano entre 1983 e 1985, modelos logit e tobit visando identificar quais os principais motivos que levam os bancos a venderem parte de suas carteiras de crédito. Para tanto, testaram variáveis relacionadas à hipóteses ligadas à arbitragem de taxas regulatórias, diversificação da carteira de crédito, restrição de fontes de financiamento e de liquidez, qualidade da carteira e vantagens comparativas na originação de operações de crédito. 
Os resultados encontrados apontam que, apesar de restrições regulatórias terem influenciado a participação dos bancos analisados no mercado de cessões, vantagens comparativas na originação e serviço das operações de crédito, bem como o nível de diversificação da carteira foram os principais determinantes da entrada dos bancos no mercado de cessões e dos montantes efetivamente cedidos (Pavel \& Phillis, 1987, p. 3). Ademais, quanto ao momento de entrada no mercado secundário de créditos, Pavel e Phillis (1987, p. 12) identificaram uma tendência de que os bancos comecem a vender parte de suas carteiras de crédito quando os índices de capital se encontram baixos ou quando as operações levadas a prejuízo estão excessivamente altas.

Gorton e Pennacchi (1995), apontando os possíveis motivos para um aumento do volume de operações de cessão de créditos - incremento dos custos de financiamento interno dos bancos via depósitos ou oportunidade de diversificação da carteira de empréstimos elaboram um modelo de garantias contratuais implícitas entre cedentes e cessionários visando o alinhamento dos incentivos para a realização de operações de cessão.

O modelo foi testado em uma amostra de mais de 800 operações de cessão realizadas entre 1986 e 1987 por um único banco norte-americano. As variáveis empregadas referemse a características individuais das operações, tais como a maturidade das operações cedidas, taxa da negociação, fração da operação de crédito que é cedida e rating de crédito no momento da cessão (Gorton \& Pennacchi, 1995, p. 404).

O resultado encontrado é consistente com o modelo proposto, confirmando previsão dos autores de que os bancos tendem a manter os empréstimos de maior grau de risco em sua carteira quando empreendem operações de cessão. Nesse modelo, a preferência por transferir os ativos com menor risco de crédito decorreria do menor prêmio exigido pelos compradores na aquisição desses ativos e pela premissa de que os vendedores oferecem garantias implícitas se comprometendo a recomprar créditos eventualmente inadimplentes (Gorton \& Pennacchi, 1995, p. 408).

Haubrich e Thomson (1996), em linha com o modelo de avaliação dos custos de financiamento bancário de Pennacchi (1988), discutem também os determinantes para a participação dos bancos no mercado secundário de operações de crédito. O porte das instituições, suas estruturas de capital e de risco, bem como estratégias de financiamento e investimento, são todos apontados como fatores significativos para a participação dos bancos nas operações de cessão de direitos creditórios (Haubrich \& Thomson, 1996, p. 149). 
O principal diferencial apresentado no trabalho de Haubrich e Thomson (1996) foi buscar analisar as cessões não somente do lado da oferta, como era comum nas pesquisas anteriores, mas também do lado da demanda, analisando especificamente os determinantes para a compra de operações de crédito por instituições bancárias.

Como resultado, encontraram indícios de que todos os fatores apontados entre os determinantes foram significativos tanto para as compras quanto para as vendas de operações de crédito (Haubrich \& Thomson, 1996, pg. 159).

Assim como Gorton e Pennacchi (1995) e Haubrich e Thomson (1996), Demsetz (2000, p. 198) avalia possíveis motivações para as cessões de crédito. Para tanto, a autora testa três fatores quanto à sua relevância para a motivação das cessões. Primeiramente, estabelece-se a hipótese de que enquanto há bancos que apresentam uma vantagem comparativa na originação de operações de crédito, há bancos com vantagem comparativa no financiamento por meio da aquisição desse tipo de operação. Os primeiros tendem a atuar mais frequentemente como cedentes, enquanto os segundos como cessionários.

O segundo fator explorado diz respeito à diversificação de carteiras, seja do ponto de vista dos setores econômicos ou da distribuição geográfica, no caso de bancos de atuação não restrita a determinadas localidades. Bancos que por algum motivo apresentam restrições ou dificuldades para diversificar suas carteiras de crédito por conta própria tenderiam a fazer isso por meio de atuação no mercado de cessões de direitos creditórios (Demsetz, 2000, p. 198).

Por fim, incorpora-se na análise em que medida problemas de assimetria informacional limitam o escopo do mercado de cessões, e como a negociação por parte de instituições integrantes de conglomerados econômico-financeiros teriam alguma influência na redução de assimetrias e, consequentemente, no volume de créditos negociados no mercado secundário (Demsetz, 2000, p. 199).

Fazendo algo que era até então atípico na literatura, Demsetz (2000, p. 203) procura estudar separadamente quatro possíveis posicionamentos das instituições no mercado de cessões: bancos que atuam apenas como cedentes, bancos que atuam apenas como cessionários, bancos que atuam nas duas posições e bancos que não têm qualquer participação no mercado secundário de créditos. Os resultados obtidos pela autora apontam que cada um desses grupos responde de uma forma específica quando considerados os determinantes testados, os quais se mostraram todos significativos para as cessões. 
Parlour e Plantin (2008, p. 1291) focam sua análise nas hipóteses de que os bancos operam no mercado secundário de créditos basicamente para reestruturarem a composição de suas carteiras ou para tirarem proveito de negociações baseadas na posse de informações privilegiadas.

Nesse sentido, argumentam que bancos com ativos mais líquidos em carteira encontram-se em posição mais favorável no que concerne ao gerenciamento de ativos e passivos, logo, dispõem de maior facilidade para redirecionamento do capital, visando o aproveitamento de melhores oportunidades de negócio, e maior resiliência a choques externos, devido à diversificação de suas exposições. Por outro lado, a maior liquidez dos ativos tende a reduzir os incentivos para monitoramento dos tomadores de crédito, haja vista a possibilidade de venda das operações apresentando baixo retorno, ainda que isso ocorra de forma não observável para os compradores, aumentando-se, assim, o risco de seleção adversa (Parlour \& Plantin, 2008, p. 1292).

Os autores constataram que o fato de as operações ocorrerem por um motivo ou pelo outro influenciaria diretamente a liquidez dos ativos sendo transacionados, sendo que, em geral, instituições com carteiras de crédito mais diversificadas disporão de maior liquidez quando da venda de seus créditos (Parlour \& Plantin, 2008, p. 1302).

Também tendo como pano de fundo a avaliação de problemas de assimetria de informações, mas com maior foco na perspectiva de risco, Altman, Gande e Saunders (2010, p. 764), comparando séries de preços diários dos ativos negociados no mercado secundário de títulos com os preços no mercado secundário de operações de crédito, evidenciam que este é relativamente mais eficiente do ponto de vista de disseminação de informações, e que, mesmo depois de cedidos os créditos, os bancos continuam exercendo importante função de monitores do desempenho das operações.

Ainda com base na ideia de que as vendas de operações de crédito por vezes decorrem do intuito de uma instituição financeira retirar de sua carteira operações com baixa qualidade creditícia, Dahiya, Puri e Saunders (2003, p. 576) constatam que o anúncio de oferta de operações de crédito no mercado secundário pode, de fato, representar uma sinalização negativa quanto à qualidade dos créditos negociados. Para tanto, os autores empreendem um estudo de eventos visando verificar a ocorrência de retornos anormais para as firmas que anunciam publicamente a venda de suas operações de crédito pelos bancos credores.

Verificando o subsequente desempenho dos devedores após a venda de seus empréstimos, os autores identificaram diversos casos de falência dos tomadores e a 
consequente inadimplência em operações de crédito pouco depois da negociação dos ativos no mercado secundário. Ao relacionarem tais acontecimentos com os retornos auferidos pelas firmas, constatam haver um efeito negativo das cessões de créditos realizadas pelos bancos sobre os retornos dos tomadores (Dahiya, Puri \& Saunders, 2003, p. 580).

Drucker e Puri (2009, p. 2852), explorando ampla base de operações de cessão realizadas no mercado norte-americano entre 1998 e 2005, verificaram que $60 \%$ dos empréstimos eram cedidos em até um mês após sua originação, e que $90 \%$ era cedido dentro de um ano. Ademais, encontraram evidências de que as cessões são frequentemente utilizadas como forma de gerenciamento do risco de crédito pelos bancos e que isso de certa forma é positivo para os tomadores, pois os clientes cujos empréstimos são cedidos apresentam maior probabilidade de conseguirem tomar crédito novamente com os mesmos bancos cedentes no futuro, sugerindo que o sucesso de operações cedidas levaria a um fortalecimento da relação entre a instituição financeira e seu cliente (Drucker \& Puri, 2009, p. 2864).

Na mesma linha de análise de risco em que seguiram Drucker e Puri (2009), Bedendo e Bruno (2012) avaliaram o uso de instrumentos de transferência de risco de crédito - cessão de direitos creditórios, securitização e derivativos de crédito - durante os anos de 2007 a 2009 no mercado norte-americano. Verificou-se que $80 \%$ das instituições financeiras que transferiram parcela de suas exposições a risco no período utilizaram apenas um dos três instrumentos estudados. As cessões de direitos creditórios se destacaram como o instrumento mais utilizado em volume, seja individualmente ou em conjunto com outros instrumentos, principalmente quando considerados a faixa de bancos de menor porte da amostra (Bedendo \& Bruno, 2012, p. 3263).

Os achados de Bedendo e Bruno (2012) são consistentes com modelo apresentado posteriormente por Parlour e Winton (2013). Embora em tal modelo as cessões de crédito sejam comparadas apenas aos derivativos de crédito, os autores demonstram como, uma vez consideradas questões reputacionais decorrentes da iteração das relações entre cedentes e cessionários, o uso das cessões de direitos creditórios como instrumento mitigador apresentam vantagens sobre os derivativos de crédito quando se trata de créditos de risco mais elevado (Parlour \& Winton, 2013, p. 41).

Ahn e Breton (2014, p. 202) constatam que a possibilidade de realização de cessões e securitizações suaviza a competição no mercado primário de crédito e possibilitam maiores lucros aos bancos na originação das operações. Por sua vez, Han, Park e Pennacchi (2015, 
p. 1288) avaliam como os impostos incidentes sobre os rendimentos bancários impactam o volume de cessões de crédito e constatam que, quanto maior a incidência de impostos, maior o número de operações cedidas, especialmente por bancos que, conforme a hipótese de vantagem comparativa testada em outros trabalhos (Demsetz, 2000), apresentam maiores oportunidades de originação de novas operações de crédito e maior restrição na captação de novos depósitos.

No que diz respeito à produção acadêmica nacional, o tema cessão de créditos é ainda pouco explorado. Ribeiro e Schiozer (2014) abordaram essas operações no mercado bancário brasileiro, buscando avaliar, especificamente, a relação entre cessões de crédito e restrição de capital.

Ribeiro e Schiozer (2014, p. 525) mostraram que, enquanto as operações de crédito no mercado brasileiro apresentaram um crescimento de $162,2 \%$ no período de análise da pesquisa, compreendido entre junho de 2004 e junho de 2009, as operações de cessão cresceram 1.937,3\%. Valendo-se do uso de um modelo Tobit em painel, os autores obtiveram resultados que indicam haver uma relação positiva entre uma maior restrição de capital - próprio e de terceiros - e a expansão das operações de cessão de créditos realizadas pelos bancos.

Já no contexto dos trabalhos sobre securitização, cabe destacar como úteis, para os fins desta pesquisa, trabalhos que buscaram determinar os principais fundamentos econômicos ou motivadores da participação dos bancos nesse mercado, por coincidirem, em grande medida, com os motivadores da cessão de direitos creditórios. Esse é o caso por exemplo, dos trabalhos de Affinito e Tagliaferri (2010), Cardone-Riportella, Samaniego-Medina e Trujillo-Ponce (2010) e Farruggio e Uhde (2015), cujas análises focam, respectivamente, o mercado italiano, o mercado espanhol e o mercado europeu como um todo.

Por sua vez, Casu, Clare, Sarkisyan e Thomas (2013) buscam verificar se a participação em operações de securitização de fato exerce um impacto significativo sobre o desempenho dos bancos. Para tanto, analisam uma extensiva lista de variáveis abrangendo diversos aspectos da atividade bancária possivelmente afetados pelas securitizações, tais como a estrutura dos balanços patrimoniais, composição das carteiras de crédito, medidas de risco e composição do capital regulatório, custos de financiamento e desempenho operacional, a fim de procederem à uma comparação entre bancos securitizadores e não securitizadores (Casu, Clare, Sarkisyan \& Thomas, 2013, p. 1631). 


\section{METODOLOGIA DE ANÁLISE}

Nesta seção, são apresentados a fonte de dados, o plano amostral, as variáveis selecionadas com base na literatura e o método utilizado para estimação dos modelos especificados com vistas à identificação dos determinantes das cessões de direitos creditórios no setor bancário brasileiro.

\subsection{Fonte de dados, população e plano amostral}

Todos os dados utilizados nesta pesquisa foram obtidos na página do Banco Central do Brasil na internet, a partir dos sistemas "50 maiores bancos e o consolidado do Sistema Financeiro Nacional" e IF.Data - dados selecionados de entidades supervisionadas (BCB, 2016a, 2016b). Nesses sistemas, foram extraídas informações dos grupos Ativo, Resultado da Intermediação Financeira e Resultado Líquido, as quais, por sua vez, correspondem a contas selecionadas para divulgação pelo BCB a partir do Plano Contábil das Instituições do Sistema Financeiro Nacional (COSIF). Os dados são trimestrais e se referem ao período compreendido entre o primeiro trimestre de 2008 e o segundo trimestre de 2016 , totalizando 34 trimestres.

Faz-se importante ressaltar que o BCB não apresenta, entre as informações para análise econômico-financeira de acesso público, dados referentes ao volume financeiro das operações de cessão, mas sim o impacto dessas operações sobre o resultado dos bancos. Dessa forma, as informações quanto às Cessões de Crédito foram identificadas no grupo "Resultado da Intermediação Financeira", no qual se apresentam as "Receitas de Vendas ou Transferência de Ativos Financeiros”, representadas por conta do COSIF destinada ao registro das operações pelos bancos cedentes, e as "Despesas com Vendas ou Transferência de Ativos Financeiros", obtidas a partir dos registros, também conforme o COSIF, das operações dos bancos que tenham realizado operações de cessão na figura de cessionários.

A seleção dos bancos para a amostra se baseou, primeiramente, na subdivisão em Tipos de Consolidado Bancário conforme definição do Banco Central do Brasil, tendo em vista incluir apenas aquelas instituições que de alguma forma podem ter participação no mercado de cessão de direitos creditórios. Dessa forma, trabalhou-se com os Consolidados Bancários I e II, os quais, de acordo com a classificação do BCB, incluem instituições financeiras do tipo banco múltiplo - com ou sem carteira comercial -, caixa econômica e 
bancos de investimento, bem como conglomerados bancários que incluem em sua composição ao menos um banco comercial, múltiplo ou de investimento. Dentro desses critérios, foram listados, inicialmente, 208 bancos no período em análise.

Dada a discrepância quanto ao número de períodos com registro de informações entre os bancos, trata-se de um painel não balanceado. Optou-se, todavia, pela exclusão apenas dos bancos com número de observações inferior a 12 trimestres, aproximadamente um terço dos 34 trimestres correspondentes ao total do período de análise, pois, apesar de tal critério ainda não ter resultado em uniformidade quanto à duração das séries históricas entre os bancos, por outro lado minimizou a perda de informação que tal procedimento provocaria sobre os registros nas contas de maior interesse, aquelas relacionadas às cessões. Dessa forma, a amostra passou a contar com um número total de 198 bancos.

Foram, em seguida, retirados da amostra mais quatro bancos: Banco Cruzeiro do Sul S.A., Banco Morada S.A, Banco Prosper S.A e Banco Rural S.A. A exclusão de tais instituições foi realizada devido a todas terem sofrido intervenção e, posteriormente, terem sido liquidadas extrajudicialmente por determinação do Banco Central do Brasil, dentro do período de análise. Sendo assim, por fim, constituiu-se amostra com um total de 194 bancos para a estimação dos modelos econométricos da pesquisa.

Com o intuito de verificar eventuais discrepâncias no comportamento dos bancos no mercado de cessões em função do porte das instituições, as análises econométricas foram realizadas considerando a amostra total, mas também duas sub-amostras: uma contendo apenas os bancos de grande porte - assim considerados os 10 maiores bancos do SFN em termos da média do volume de ativos no período de análise -, e uma segunda contendo os demais bancos.

Tal subdivisão de justifica pelo fato de que, no que concerne ao tamanho das instituições, bancos de grande porte geralmente apresentam, em comparação com os pequenos e médios, vantagens comparativas na originação de novas operações de crédito e, ao mesmo tempo, custos de financiamento mais elevados, o que favoreceria sua atuação no mercado de cessões no papel de cedentes. Todavia, custos fixos associados com as compras e vendas de carteiras podem justificar os bancos grandes a participar nas duas posições do mercado de cessão (Demsetz, 2000, p. 205).

Quanto aos bancos pequenos e médios, quanto maior a dificuldade para tais instituições constituírem carteiras de crédito diversificadas diretamente, por meio da originação de diferentes tipos de empréstimos, maior o incentivo para que participem 
ativamente tanto como cedentes quanto como cessionários. Por outro lado, em contextos em que se impõem limites mais rígidos, sejam legais ou regulatórios, para os montantes de operações de crédito que tais bancos podem originar, mais provável que participem apenas entre os vendedores (Demsetz, 2000, p. 205).

\subsection{Variáveis em estudo}

A seleção de variáveis para a estimação econométrica foi realizada considerando-se os principais determinantes, sob a perspectiva teórica, apontados pela literatura, quais sejam: as alternativas de financiamento e as necessidades de liquidez dos bancos, a rentabilidade e diversificação das instituições, o risco - tanto de insolvência da instituição quanto específico da carteira de crédito -, e possibilidades de arbitragem de capital regulatório.

Embora a maior parte das variáveis tenha sido construída exatamente como aplicadas em pesquisas empíricas correlatas, há outras que, embora sejam também representativas dos construtos considerados na análise, tiveram que ser substituídas por proxies, dada a indisponibilidade dos mesmos tipos de dados na base compilada a partir das informações publicadas pelo Banco Central do Brasil. Os casos em que tal procedimento se fez necessário são devidamente apontados a seguir.

\section{Cessão (venda) de direitos creditórios (Ven_dc)}

Variável dependente binária, correspondente a 1 (um) quando o banco vende operações de crédito e 0 (zero) quando não o faz.

A partir dos dados coletados para a pesquisa, os bancos cedentes foram identificados quando observados registros na conta de "Receitas com Operações de Venda ou Transferência de Ativos Financeiros".

\section{Compra de direitos creditórios (Com_dc)}

Variável dependente utilizada para identificação dos cessionários em operações de cessão de direitos creditórios, correspondente a 1 (um) quando o banco compra operações de crédito e 0 (zero) quando não o faz. 
Para identificação dos bancos cessionários, observou-se, na base de dados, registro na conta de "Despesas com Operações de Venda ou Transferência de Ativos Financeiros".

\section{Receitas com a venda de ativos financeiros / Total das receitas de intermediação financeira (Rec_cc)}

Variável dependente na análise do impacto dos determinantes das cessões sobre a magnitude do resultado financeiro das operações para os bancos cedentes.

Embora pesquisas anteriores tenham buscado avaliar a magnitude dos fluxos de cessões em relação ao total dos ativos dos bancos (Haubrich \& Thomson, 1996, p. 148; Affinito \& Tagliaferri, 2010, p. 192; Farruggio \& Uhde, 2015, p. 15), ou em relação ao total da carteira de crédito (Ribeiro \& Schiozer, 2014, p. 524), nesta pesquisa o foco está na análise do quanto as variáveis independentes afetam o montante das receitas auferidas com as vendas de direitos creditórios em relação à totalidade das receitas de intermediação financeira dos bancos, tratando-se, portanto, não dos volumes financeiros das operações transacionadas, mas sim do impacto das transações sobre o resultado dos bancos.

\section{Despesas com a compra de ativos financeiros / Total das despesas de intermediação financeira (Desp_cc)}

Variável dependente na análise do impacto dos determinantes das cessões sobre a magnitude do resultado financeiro das operações para os bancos cessionários.

\section{Fontes de financiamento e necessidades de liquidez}

Em um mercado de crédito sem fricções, recursos estariam disponíveis para quaisquer tomadores que dispusessem de projetos com um valor presente líquido positivo. Dessa forma, para que haja vantagens na cessão de crédito da perspectiva dos custos de alternativas de financiamento, portanto, faz-se necessária a existência de algum tipo de restrição ou empecilho na obtenção de recursos a serem destinados à originação de empréstimos. (Drucker \& Puri, 2009, p. 2840).

Espera-se, portanto, que eventuais restrições quanto às fontes de financiamento à disposição dos bancos aumentem a probabilidade de que vendam parte de sua carteira de 
crédito (Demsetz, 2000, pg. 204). Para mensuração do grau de restrição do capital à disposição para financiamento dos bancos, utiliza-se, nesta pesquisa, a razão entre Depósitos e o Ativo Total (Dep/AT).

Dessa forma, como se espera que bancos com restrição de capital vendam créditos, espera-se um sinal negativo para a variável (Haubrich \& Thomson, 1996, p. 148; Demsetz, 2000, p. 204), quando se trata da perspectiva dos cedentes, pois uma maior disponibilidade de depósitos indicaria menor necessidade de fontes alternativas de financiamento (Affinito \& Tagliaferri, 2010, p. 192).

Entretanto, como se busca identificar os determinantes tanto para cedentes quanto para cessionários, a expectativa quanto ao sinal se inverte para os bancos comprando direitos creditórios, já que faz sentido que bancos com folga de capital estejam mais propensos a comprar operações de crédito, e não a vendê-las (Haubrich \& Thomson, 1996, p. 150).

Também do ponto de vista de necessidade de liquidez para investimento em novas operações, utiliza-se a variável Crescimento da Carteira de Crédito. Tal variável permite avaliar o desenvolvimento da atividade bancária e a necessidade de recursos para a expansão da carteira de crédito. Uma elevada necessidade de liquidez é refletida pelo alto crescimento da carteira de crédito, sendo esperado, portanto, sinal positivo para a variável (Affinito \& Tagliaferri, 2010, p. 195; Casu, Clare, Sarkysian \& Thomas, 2013, p. 1637).

\section{Rentabilidade e Diversificação}

No que diz respeito a diversificação, seja de atividades ou de composição da carteira de crédito, os bancos podem recorrer às cessões de direitos creditórios por variados motivos. As cessões servem como mecanismo para que as instituições possam mudar a composição de ativos da carteira, eliminando eventuais excessos de determinados tipos de empréstimos para a realização de novas concessões, contemplando diferentes produtos de crédito, taxas ou perfil de clientes. Ademais, os bancos podem buscar nas cessões uma forma de alterarem a maturidade média da carteira de crédito, de aumentarem a diversificação geográfica de suas operações de uma maneira mais simples do que com a abertura de filiais em outras localidades, ou até mesmo para reduzirem o peso do crédito em suas receitas, visando maior atuação em atividades não relacionadas à intermediação financeira (Haubrich \& Thomson, 1996, p. 140). 
Nesta perspectiva de diversificação, as cessões de direitos creditórios podem ter dois efeitos contrários. As cessões permitem que os bancos vendam determinados tipos de operações a fim de obterem tanto os recursos necessários quanto folga de capital regulatório exigido para a originação de outros tipos de ativos para a carteira de crédito, ou até mesmo revertendo os recursos para atividades não ligadas diretamente à intermediação financeira. Por outro lado, a depender do perfil e das estratégias de negócios dos bancos, pode ser que busquem justamente o contrário: aumentar a concentração da carteira de crédito, por meio de maior foco na originação de operações para as quais apresentem vantagens comparativas, aproveitando economias de escala (Affinito \& Tagliaferri, 2010, p. 195).

Embora Affinito e Tagliaferri (2010) e Casu, Clare, Sarkysian e Thomas (2013) utilizem a razão entre as Receitas não relacionadas a Juros sobre Receitas de Juros para aferir o nível de diversificação da atividade dos bancos, utiliza-se, nesta pesquisa, pela indisponibilidade dos dados referentes às receitas auferidas especificamente com juros, uma proxy, qual seja, as Receitas não relacionadas à Intermediação Financeira sobre as Receitas de Intermediação Financeira. Por estas considerarem toda a atividade de intermediação dos bancos, trata-se de contas que englobam outras rendas, além das auferidas com juros, tais como as receitas com instrumentos derivativos, perdendo-se, portanto, em especificidade, dado impossibilitar o foco da análise em receitas decorrentes de operações com característica de crédito. Não obstante, ainda assim permitem avaliação quanto à diversificação de atividades dos bancos, por diferenciarem as receitas de intermediação de outras receitas operacionais.

Mas apesar da utilização de tais proxies, os sinais esperados não se alteram. Caso as cessões sejam utilizadas para fins de maior diversificação, quanto menos diversificado o banco, maior a probabilidade de que venha a ceder créditos, e, portanto, o sinal será negativo. Do contrário, caso bancos com maior diversificação busquem aumentar a concentração de suas operações em atividades de intermediação por meio das cessões, o sinal será positivo (Affinito \& Tagliaferri, 2010, p. 195, Casu, Clare, Sarkysian \& Thomas, 2013, p. 1637).

Já no que concerne especificamente à apuração da busca por maior rentabilidade por meio das cessões, inclui-se no presente estudo variável comumente utilizada para mensuração dos retornos sobre o capital dos acionistas, o Retorno sobre o Patrimônio Líquido (ROE), já que os bancos podem buscar, por meio da aquisição ou da venda de carteiras de crédito, um aumento de lucratividade (Affinitto \& Tagliaferri, 2010, p. 193). 
O sinal esperado para essa variável é ambíguo, pois, se por um lado o objetivo de se aumentar os retornos dos bancos pode motivar as operações de cessão, isto é, um baixo ROE relacionando-se a maior probabilidade de cessão (Bannier \& Hänsel, 2008), por outro, a depender do apetite a risco da instituição, é possível que bancos apresentando maiores retornos sejam também particularmente ativos nessas operações (Cardone-Riportella, Samaniego-Medina \& Trujillo-Ponce, 2010, p. 2.642).

\section{Arbitragem de capital regulatório}

Elevados requerimentos de capital podem ser altamente custosos para os bancos, tanto do ponto de vista do custo efetivo de manutenção em carteira dos ativos financeiros elegíveis para a composição de capital regulatório, quanto dos custos de oportunidade envolvidos, dadas as restrições para a livre destinação dessa parcela do capital da instituição ao investimento em operações potencialmente lucrativas.

Nesse sentido, exigências regulatórias frequentemente obrigam os bancos a reservarem níveis de capital mais elevados do que fariam na ausência de regulação, reduzindo a lucratividade decorrente da manutenção de certos tipos de operação em carteira até o vencimento (Pavel \& Phillis, 1987, pg. 7). Dessa forma, espera-se que elevadas exigências de reservas de capital estejam relacionadas com uma maior probabilidade de realização de cessões (Cardone-Riportella, Samaniego-Medina \& Trujillo-Ponce, 2010, p. 2.642; Farruggio \& Uhde, 2015, p. 13).

Por representar, atualmente, a principal medida do cumprimento pelos bancos de requerimentos de capital regulatório, utiliza-se como variável o Índice de Basileia (IB). Este índice aponta o requerimento regulatório mínimo de capital imposto aos bancos brasileiros, em observância às recomendações internacionais emitidas pelo Comitê de Supervisão Bancária da Basileia (BCBS), organismo integrante do Banco de Compensações Internacionais (BIS).

O IB consiste na razão entre o capital da instituição elegível para fins regulatórios e os ativos ponderados pelo risco. Por entender-se que as cessões de direitos creditórios são, possivelmente, uma forma utilizada pelos bancos com o intuito de reduzirem o requerimento de capital a que estão sujeitos, espera-se um sinal negativo para essa variável (Affinito \& Tagliaferri, 2010, p. 193). Já da perspectiva dos cessionários, é de se esperar que 
predominantemente os bancos com folga em relação ao requerimento mínimo possam adquirir novas operações de crédito para suas carteiras.

\section{Risco bancário}

Espera-se uma relação positiva entre cessões de direitos creditórios e medidas de risco, seja em decorrência de o banco estar utilizando as cessões como forma de retirar operações de baixa qualidade creditícia de seu balanço, no caso dos cedentes, ou por identificar possibilidade de maior concentração de suas operações em ativos de alto risco a fim de explorar eventual sub-apreçamento de seguros de depósitos ou provisões, no caso dos cessionários (Haubrich \& Thomson, 1996, pg. 147).

O Z-score representa uma medida do risco de insolvência da instituição. Seu resultado indica em quantos desvios-padrão o ROA do banco precisa decrescer para que ele se torne insolvente. Tal indicador é interpretado, portanto, como a probabilidade inversa de insolvência do banco, logo, maiores valores para o Z-score indicam menor risco (Tabak, Fazio \& Cajueiro, 2013, p. 3858).

Calcula-se o Z-score procedendo-se a seguinte razão:

$$
Z-\text { Score }=\frac{R O A+\frac{\text { Patrimônio Líquido }}{\text { Ativo Total }}}{\sigma_{R O A}}
$$

Para fins deste trabalho, seguiu-se Bedendo e Bruno (2012, p. 3272), utilizando-se, portanto, uma janela móvel de quatro trimestres para o cálculo do ROA médio, do índice de capital médio e do desvio-padrão médio do ROA.

Visando-se também analisar mais especificamente o risco de inadimplência na carteira de crédito dos bancos, utiliza-se neste trabalho medida de risco referente ao grau de provisionamento da carteira, representado pelo índice Provisões para Créditos de Liquidação Duvidosa (PCLD) sobre o total da carteira de Operações de Crédito e Arrendamento Mercantil.

Este índice indica quanto do total da carteira de crédito do banco está coberto por reservas destinadas à cobertura de eventuais inadimplências. As provisões representam uma reserva para absorção de perdas esperadas em uma porcentagem dos créditos concedidos, de forma que um maior valor para tal índice aponta uma menor qualidade da carteira de crédito, 
e, portanto, maior risco (Cardone-Riportella, Samaniego-Medina \& Trujillo-Ponce, 2010, p. 2641; Farruggio \& Uhde, 2015, p. 16).

\section{Controle Acionário}

Há ainda outras variáveis que, embora nem sempre sejam discutidas na literatura entre os principais determinantes das cessões do ponto de vista econômico-financeiro, supõe-se que possam exercer influência sobre a decisão de participação nesse mercado ou na magnitude das operações no contexto brasileiro. Nesse sentido, são também inclui-se nos modelos a variável Tipo de Controle Acionário.

A variável Tipo de Controle Acionário (D_TCA) é uma dummy que assume valor igual a 1 quando se trata de bancos públicos e 0 quando o controle é privado, seja nacional ou estrangeiro. Conforme apontado anteriormente, em Relatório de Estabilidade Financeira publicado recentemente pelo Banco Central do Brasil (BCB, 2015) deu-se destaque, no ano de 2015, ao maior envolvimento de bancos públicos na realização de operações de cessão de direitos creditórios. Por outro lado, conforme anteriormente destacado quando da descrição da evolução do mercado de cessões no Brasil, alguns dos fatos mais relevantes ocorridos no país nesse segmento envolviam a participação de bancos privados. Dessa forma, o sinal esperado para essa variável é ambíguo, de forma a impor a necessidade de sua verificação na prática.

O Quadro 2 apresenta uma compilação das variáveis listadas e as referências de sua utilização em pesquisas anteriores.

Quadro 2 - Variáveis utilizadas na pesquisa.

\begin{tabular}{|l|l|}
\hline \multicolumn{1}{|c|}{ Variáveis } & \multicolumn{1}{c|}{ Referências na literatura } \\
\hline Dummy para vendas de direitos creditórios & $\begin{array}{l}\text { Haubrich e Thomson (1996), Demsetz (2000), Affinito e } \\
\text { Tagliaferri (2010), Cardone-Riportella, Samaniego-Medina e } \\
\text { Trujillo-Ponce (2010), Farruggio e Uhde (2015). }\end{array}$ \\
\hline $\begin{array}{l}\text { Dummy para compras de direitos } \\
\text { creditórios }\end{array}$ & Haubrich e Thomson (1996), Demsetz (2000). \\
\hline $\begin{array}{l}\text { Receitas com cessão de direitos creditórios } \\
\text { / Receitas de Intermediação Financeira }\end{array}$ & $\begin{array}{l}\text { Proxy para os trabalhos que utilizaram Fluxo de Cessões / Ativo } \\
\text { Total ou Fluxo de Cessões / Carteira de Crédito. }\end{array}$ \\
\hline $\begin{array}{l}\text { Despesas com cessão de direitos } \\
\text { creditórios / Despesas de Intermediação }\end{array}$ & $\begin{array}{l}\text { Froxy para os trabalhos que utilizaram como variável as Compras } \\
\text { de operações de crédito / Ativo Total. }\end{array}$ \\
\hline
\end{tabular}




\begin{tabular}{|l|l|}
\hline Depósito Total / Ativo Total & $\begin{array}{l}\text { Bannier e Hänsel (2008), Affinito e Tagliaferri (2010); Ribeiro e } \\
\text { Schiozer (2014). }\end{array}$ \\
\hline Crescimento da carteira de crédito & $\begin{array}{l}\text { Pavel e Phillis (1987), Affinito e Tagliaferri (2010) } \\
\text { Casu, Clare, Sarkysian e Thomas (2013). }\end{array}$ \\
\hline Z-score & Bedendo e Bruno (2012), Farruggio e Uhde (2015). \\
\hline PCLD / Carteira de Crédito & $\begin{array}{l}\text { Demsetz (2000), Cardone-Riportella, Samaniego-Medina e } \\
\text { Trujillo-Ponce (2010), Farruggio e Uhde (2015). }\end{array}$ \\
\hline Índice de Basileia & $\begin{array}{l}\text { Cardone-Riportella, Samaniego-Medina e Trujillo-Ponce (2010), } \\
\text { Affinito e Tagliaferri (2010), Farruggio e Uhde (2015). }\end{array}$ \\
\hline $\begin{array}{l}\text { Receita não intermediação financeira / } \\
\text { Receitas de intermediação financeira }\end{array}$ & $\begin{array}{l}\text { Proxy para a variável "Receitas não relacionadas a juros / } \\
\text { eceitas de juros", utilizada em: Pavel e Phillis (1987), Affinito } \\
\text { e Tagliaferri (2010) e Casu, Clare, Sarkysian e Thomas (2013). }\end{array}$ \\
\hline ROE & $\begin{array}{l}\text { Bannier \& Hänsel, (2008), Affinito e Tagliaferri (2010); } \\
\text { Cardone-Riportella, Samaniego-Medina e Trujillo-Ponce (2010), } \\
\text { Casu, Clare, Sarkysian e Thomas (2013), Farruggio e Uhde } \\
\text { (2015). }\end{array}$ \\
\hline Tipo de Controle Acionário & - \\
\hline
\end{tabular}

Na tabela 2 abaixo encontra-se a estatística descritiva das variáveis da pesquisa. 
Tabela 2 - Estatística Descritiva das Variáveis da Pesquisa

\begin{tabular}{|c|c|c|c|c|c|c|c|c|c|c|c|c|}
\hline \multirow[b]{2}{*}{ Variáveis } & \multicolumn{4}{|c|}{ Amostra Total } & \multicolumn{4}{|c|}{ Bancos Grandes } & \multicolumn{4}{|c|}{ Demais Bancos } \\
\hline & Média & Mediana & $\begin{array}{c}\text { Desvio } \\
\text { Padrão } \\
\end{array}$ & Obs & Média & Mediana & $\begin{array}{c}\text { Desvio } \\
\text { Padrão } \\
\end{array}$ & Obs & Média & Mediana & $\begin{array}{c}\text { Desvio } \\
\text { Padrão }\end{array}$ & Obs \\
\hline Dummy venda de direitos creditórios & 0.0875 & 0.0000 & 0.2825 & 4.516 & 0.4375 & 0.0000 & 0.4968 & 336 & 0.0594 & 0.0000 & 0.2363 & 4.178 \\
\hline Dummy compra de direitos creditórios & 0.1661 & 0.0000 & 0.3722 & 4.516 & 0.4762 & 0.0000 & 0.5002 & 336 & 0.1412 & 0.0000 & 0.3483 & 4.178 \\
\hline $\begin{array}{l}\text { Receitas com Cessão / Receitas de Intermediação } \\
\text { Financeira }\end{array}$ & 0.0016 & 0.0000 & 0.0132 & 4.516 & 0.0011 & 0.0000 & 0.0032 & 336 & 0.0016 & 0.0000 & 0.0137 & 4.178 \\
\hline $\begin{array}{l}\text { Despesas com Cessão / Despesas de Intermediação } \\
\text { Financeira }\end{array}$ & -0.0106 & 0.0000 & 1.8719 & 4.516 & 0.0082 & 0.0000 & 0.0329 & 336 & -0.0121 & 0.0000 & 1.9461 & 4.178 \\
\hline Depósito Total / Ativo Total & 0.9352 & 0.2924 & 24.9616 & 4.516 & 6.8231 & 0.2833 & 89.3313 & 336 & 0.4620 & 0.2937 & 5.5208 & 4.178 \\
\hline Crescimento da Carteira de Crédito & 0.1916 & 0.0111 & 4.3661 & 4.516 & 0.0562 & 0.0339 & 0.2123 & 336 & 0.2026 & 0.0071 & 4.5387 & 4.178 \\
\hline $\begin{array}{l}\text { Receitas não intermediação / Receitas Intermediação } \\
\text { Financeira }\end{array}$ & 5.6439 & 0.1678 & 263.3685 & 4.516 & 59.1275 & 0.2628 & 961.6930 & 336 & 1.3453 & 0.1593 & 23.5145 & 4.178 \\
\hline ROE & -0.0008 & 0.0254 & 0.7492 & 4.516 & 0.0600 & 0.0547 & 0.0475 & 336 & -0.0057 & 0.0230 & 0.7786 & 4.178 \\
\hline Índice de Basileia & 39.8847 & 18.9592 & 168.3637 & 4.242 & 16.2728 & 15.6326 & 3.3921 & 316 & 41.7852 & 19.8000 & 174.8687 & 3.926 \\
\hline Z-Score & 45.4758 & 34.5779 & 50.2401 & 4.516 & 43.5084 & 33.3461 & 40.4985 & 336 & 45.6406 & 34.8553 & 50.9543 & 4.178 \\
\hline PCLD / Carteira de Crédito & -0.0546 & -0.0345 & 0.0856 & 4.516 & -0.0555 & -0.0614 & 0.0258 & 336 & -0.0545 & -0.0323 & 0.0886 & 4.178 \\
\hline Tipo de Controle Acionário & 0.0981 & 0.0000 & 0.2975 & 4.516 & 0.3036 & 0.0000 & 0.4605 & 336 & 0.0816 & 0.0000 & 0.2738 & 4.178 \\
\hline
\end{tabular}

Fonte: Elaborada pelo autor. 


\subsection{Modelagem Econométrica}

Sendo o intuito deste trabalho identificar os determinantes das cessões de direitos creditórios, a especificação da modelagem econométrica é feita de forma a permitir, primeiramente, a verificação empírica de quais fatores influem na propensão de os bancos atuarem no mercado secundário de créditos. Ademais, cabe ressaltar, visa-se também a análise de eventuais diferenças entre os fatores mais importantes na determinação da probabilidade de as instituições atuarem vendendo (cedentes) ou comprando (cessionárias) as operações de crédito.

Para tanto, são analisados, entre os regressores, variáveis representativas dos quatro principais motivadores para as cessões apontados na literatura, reitere-se: fontes de financiamento/liquidez, diversificação de atividade e rentabilidade, risco da carteira de crédito e arbitragem de capital regulatório.

Em trabalhos anteriores, trazem-se variadas formas de separação dos bancos para análise da probabilidade de optarem pela entrada no mercado de cessões. Parte da literatura empírica segregou os bancos apenas entre não cedentes e cedentes (Pavel \& Phillis, 1987, p. 7; Farruggio \& Uhde, 2015, p. 14). Entre estes, encontra-se também a subdivisão entre cedentes recorrentes - os que efetuaram operações de cessão em todos os períodos do estudo - e cedentes eventuais - efetuaram operações apenas em alguns períodos (Pavel \& Phillis, 1987, p. 7).

Um número menor de trabalhos buscou captar os determinantes das cessões não somente para os cedentes como também para os cessionários. Para tanto, há pesquisas segregando os bancos da amostra apenas entre o lado da oferta e o da demanda das operações (Haubrich \& Thomson, 1996, p. 144), ou que os segregam em quatro posicionamentos distintos: bancos apenas cedentes, bancos apenas cessionários, bancos que atuam de ambas as formas e bancos que não participam do mercado de cessões (Demsetz, 2000, p. 198).

Neste trabalho, busca-se verificar os determinantes das cessões segregando-se os bancos apenas entre cedentes e cessionários, por meio da identificação das contas contábeis concernentes aos registros das operações de bancos vendedores e bancos compradores. Todavia, não foi estabelecido critério quanto a recorrência das cessões, de forma que apenas a realização ou não de operações durante o período de análise foi observada para separação dos bancos, independentemente do número de cessões realizadas. 
As equações das regressões realizadas na pesquisa são apresentadas a seguir, diferenciando-se apenas pelas variáveis dependentes. As equações (1) e (2) visam, respectivamente, a estimação dos determinantes da decisão de os bancos venderem ou comprarem direitos creditórios.

$$
\begin{aligned}
& \left(V e n_{-} d c\right)_{i, t}=\beta_{0}+\beta_{1}(\operatorname{Dep} / A T)_{i, t-1}+\beta_{2}\left(\text { Cresc_cc }_{i, t-1}\right. \\
& +\beta_{3}(\text { Rec_nint } / \text { Rec_int })_{i, t-1}+\beta_{4}(R O E)_{i, t-1}+\beta_{5}(I B)_{i, t-1} \\
& +\beta_{6}(Z-\text { score })_{i, t-1}+\beta_{7}(P C L D / c c)_{i, t-1}+\beta_{8}\left(D_{-} T C A\right)_{i, t}+\varepsilon_{i, t} \\
& \left(C_{-}{ }_{-} d c\right)_{i, t}=\beta_{0}+\beta_{1}(\operatorname{Dep} / A T)_{i, t-1}+\beta_{2}(\text { Cresc_cc })_{i, t-1} \\
& +\beta_{3}\left(R e c \_n i n t / R e c_{-} \text {int }\right)_{i, t-1}+\beta_{4}(R O E)_{i, t-1}+\beta_{5}(I B)_{i, t-1} \\
& +\beta_{6}(Z-\text { score })_{i, t-1}+\beta_{7}(P C L D / c c)_{i, t-1}+\beta_{8}\left(D_{-} T C A\right)_{i, t}+\varepsilon_{i, t}
\end{aligned}
$$

Sendo:

- $\left(V e n \_d c\right)_{i, t}$ : Dummy equivalente a 1 quando o banco $i$ vende operações de crédito no período $t$ e a 0 , caso contrário;

- $(\text { Com_dc })_{i, t}:$ Dummy equivalente a 1 quando o banco $i$ compra operações de crédito no período $t$ e a 0 , caso contrário;

- $(D e p / A T)_{i, t-1}$ : Depósito Total sobre o Ativo Total do banco $i$ no período $t$ - 1 ;

- $(\text { Cresc_cc })_{i, t-1}$ : Crescimento da carteira de crédito do banco $i$ no período $t-1$;

- $(\text { Rec_nint/Rec_int })_{i, t-1}$ : Total das receitas não relacionadas à intermediação financeira sobre as Receitas de intermediação financeira do banco $i$ no período $t$-1;

- $(R O E)_{i, t-1}$ : Retorno sobre o Patrimônio Líquido do banco $i$ no período $t$-1;

- $(I B)_{i, t-1}$ : Índice de Basileia do banco $i$ no período $t-1$;

- $\left(Z-\right.$ score $_{i, t-1}$ : Z-score do banco $i$ no período $t-1$;

- $(P C L D / C C)_{i, t-1}$ : Provisão para Créditos de Liquidação Duvidosa sobre o total da carteira de crédito e arrendamento mercantil do banco $i$ no período $t-1$; 
- $\left(D_{-} T C A\right)_{i, t}$ : Dummy referente ao Tipo de Controle Acionário da instituição no período $t$, correspondendo a 1 para bancos públicos e 0 para bancos privados; e

Já para avaliação do impacto das operações sobre o resultado financeiro dos bancos, foram especificadas outras duas variações da equação de regressão, novamente diferenciadas apenas pelas variáveis dependentes. Enquanto na equação (3) tem-se como variável resposta as receitas auferidas com as cessões de créditos sobre o total das receitas de intermediação financeira, $\left(\operatorname{Rec} c_{-} c c\right)_{i, t}$, a fim de se identificar a influência das variáveis independentes sobre a magnitude das receitas auferidas pelos cedentes em relação ao total de suas receitas com intermediação financeira, na equação (4) as despesas incorridas com as cessões sobre o total das despesas de intermediação financeira $\left(\operatorname{Desp}_{-} c c\right)_{i, t}$ entram como variável dependente, visando o mesmo tipo de análise, mas da perspectiva dos cessionários.

$$
\begin{aligned}
& \left(\operatorname{Rec}_{-} c c\right)_{i, t}=\beta_{0}+\beta_{1}(\operatorname{Dep} / A T)_{i, t-1}+\beta_{2}\left(\text { Cresc_cc }_{i, t-1}\right. \\
& +\beta_{3}(\text { Rec_nint } / \text { Rec_int })_{i, t-1}+\beta_{4}(R O E)_{i, t-1}+\beta_{5}(I B)_{i, t-1} \\
& +\beta_{6}(Z-\text { score })_{i, t-1}+\beta_{7}(P C L D / c c)_{i, t-1}+\beta_{8}\left(D_{-} T C A\right)_{i, t}+\varepsilon_{i, t} \\
& (\text { Desp_cc })_{i, t}=\beta_{0}+\beta_{1}(\text { Dep } / A T)_{i, t-1}+\beta_{2}\left(\text { Cresc_cc }_{i, t-1}\right. \\
& +\beta_{3}\left(R e c \_n i n t / R e c \_i n t\right)_{i, t-1}+\beta_{4}(R O E)_{i, t-1}+\beta_{5}(I B)_{i, t-1} \\
& +\beta_{6}(Z-\text { score })_{i, t-1}+\beta_{7}(P C L D / c c)_{i, t-1}+\beta_{8}\left(D_{-} T C A\right)_{i, t}+\varepsilon_{i, t}
\end{aligned}
$$

\subsection{Método de estimação}

Seguindo-se pesquisas anteriores cujo intuito se assemelha ao deste trabalho, identificou-se como o método mais adequado para a consecução dos testes econométricos a regressão logit, para estimação da probabilidade de que os bancos atuem no mercado de cessões de direitos creditórios, e a regressão tobit, para determinação dos impactos das operações sobre o resultado de intermediação financeira dos bancos. Abordagem similar foi empregada, nas pesquisas de Pavel e Phillis (1987), Haubrich e Thomson (1996), Demsetz (2000), Affinito e Tagliaferri (2010), Cardone-Riportella, Samaniego-Medina e TrujilloPonce (2010) e Farruggio e Uhde (2015), muito embora, nessas pesquisas, os modelos tobit 
tenham sido utilizados para mensurar o montante das cessões e não propriamente as receitas e despesas resultantes das operações.

O logit especificado no presente contexto representa um modelo de escolha binária para a decisão de os bancos realizarem ou não cessões de direitos creditórios, sendo que esta escolha depende do conjunto de variáveis representativas das diversas características específicas dos bancos ora apontadas como determinantes em potencial para as operações. Ou seja, o logit permite a análise do impacto das variáveis explicativas sobre a probabilidade de os bancos realizarem cessões de direitos creditórios (Farruggio \& Uhde, 2015).

Sendo o modelo logit estimado na forma

$$
p_{i}=\frac{1}{1+e^{-\left(\beta_{0}+\beta_{1} x_{1}+\beta_{2} x_{2}+\ldots+\beta_{k} x_{k}\right)+\varepsilon}}
$$

onde $p_{i}$ é a probabilidade de $y_{i}=1$, trata-se de um modelo não linear, estimável, portanto, por máxima verossimilhança (Brooks, 2014, p. 562).

No que concerne às especificações que têm como resposta os montantes de receitas e despesas apuradas com as operações, faz-se adequada a estimação de modelo destinado à utilização de variáveis dependentes limitadas, pelo elevado número de observações iguais a zero para a variável dependente (Haubrich \& Thomson, 1996, p. 146). O uso do tobit, neste caso, permite que sejam também incorporados à análise estatística os bancos que não participam do mercado de cessão, sem que se ignore a informação primordial, concernente aos montantes financeiros relacionados com as operações de cessão sobre o resultado de intermediação financeira dos bancos que de fato se inserem nesse mercado (Farruggio \& Uhde, 2015, p. 18).

Tecnicamente, os modelos tobit são aplicáveis quando os valores para a variável dependente são limitados em um certo ponto, de modo que valores superiores ou inferiores a tal ponto de corte não são observados (Brooks, 2014, 581). Entretanto, apresentam maior sensibilidade à heteroscedasticidade (Farruggio \& Uhde, 2015, p. 18). Para mitigação desse problema, as estimações em tobit foram realizadas com erros padrões robustos (Brooks, 2014, p. 585). Assim como o logit, estima-se o tobit por máxima verossimilhança.

Dadas as características da base de dados do estudo, ambos os modelos de regressão são aplicados conforme suas especificações para dados em painel. Como vantagens da aplicação a dados em painel, podem ser apontadas a consideração da heterogeneidade das 
unidades de observação e a maior variabilidade, menor colinearidade entre variáveis e maior eficiência das técnicas em decorrência da combinação de cortes transversais com séries temporais (Baltagi, 2008, p. 3).

\subsection{Testes estatísticos da base de dados}

O uso de dados em painel impõe a verificação da estacionariedade das séries de dados, assim como no caso em que se trabalha exclusivamente com séries temporais. A estacionariedade pode ser definida como a condição em que uma série de dados apresenta, média, variância e autocovariâncias constantes.

Tal condição é essencial para a realização de estimações econométricas pois a não estacionariedade pode influenciar fortemente o comportamento e as propriedades estatísticas da série de dados. Em séries não estacionárias, um choque em um período de tempo $t$ qualquer pode se reproduzir indefinidamente no tempo, levando a processos explosivos, pode induzir a realização de regressões espúrias, dado que regressões entre variáveis apresentando tendências determinísticas podem apresentar alto $\mathrm{R}^{2}$ ainda que as variáveis não tenham qualquer tipo de relação entre si, e as premissas básicas para uma análise assintótica serão violadas, pois as distribuições dos dados não corresponderão a qualquer das distribuições usualmente empregadas nos testes estatísticos de hipóteses (Brooks, 2014, p. $354)$.

Vários são os testes de estacionariedade possíveis, cada um com especificidades no que concerne à base de dados em questão. Neste estudo, optou-se pela utilização do teste Dickey-Fuller Aumentado (ADF) em painel, o qual permite a avaliação de cada conjunto de séries para cada variável separadamente.

\section{ANÁLISE DOS RESULTADOS}

\subsection{Testes de estacionariedade da base de dados}

Em seguida são apresentados os primeiros resultados dos testes de estacionariedade do painel. Foram realizados testes tanto verificando-se apenas o intercepto quanto o intercepto 
com tendência. Conforme se verifica na Tabela 3, apenas para a variável Dep/AT não foi possível rejeitar a hipótese nula do teste, que é a de existência de raiz unitária na série, indicando, portanto, a não estacionariedade dessa variável.

Tabela 3 - Testes de raiz unitária das variáveis em nível.

\begin{tabular}{ccc}
\hline Variável & $\begin{array}{c}\text { Com } \\
\text { intercepto }\end{array}$ & $\begin{array}{c}\text { Com intercepto e } \\
\text { com tendência }\end{array}$ \\
\hline Crescimento da carteira de crédito & 1745,78 & 2138,37 \\
Depósito Total / Ativo Total & $(0,0000)$ & $(0,0000)$ \\
Despesas com Cessão / Despesas de Intermediação Financeira & 371,969 & 326,729 \\
Índice de Basileia & $\mathbf{( 0 , 0 8 5 9 )}$ & $\mathbf{( 0 , 5 0 9 4 )}$ \\
& 340,680 & 287,433 \\
PCLD / Carteira de Crédito & $(0,0000)$ & $(0,0000)$ \\
& 693,357 & 618,283 \\
Receitas com cessão / Receitas de Intermediação Financeira & $(0,0000)$ & $(0,0000)$ \\
Receitas não Intermediação / Receitas de Intermediação & 515,653 & 694,535 \\
Financeira & $(0,0000)$ & $(0,0000)$ \\
& 118,361 & 104,111 \\
ROE & $(0,0002)$ & $(0,0032)$ \\
& 832,336 & 707,045 \\
Z-score & $(0,0000)$ & $(0,0000)$ \\
& 851,042 & 726,051 \\
& $(0,0000)$ & $(0,0000)$ \\
& 724,189 & 502,821 \\
& $(0,0000)$ & $(0,0000)$ \\
\hline
\end{tabular}

Nota: p-valor entre parênteses.

Dados tais resultados, refez-se o teste, em seguida, sobre a primeira diferença da variável Dep/AT apenas, a fim de se verificar a estacionariedade da série nessa condição, o que seria o esperado no caso de séries integradas de ordem I (Brooks, 2014, p. 357).

Conforme resultado da Tabela 4, observa-se a estacionariedade da série composta pela primeira diferença da variável Dep/AT. É essa, portanto, a série utilizada nas estimações dos modelos da pesquisa.

Tabela 4 - Teste de raiz unitária da variável Dep/AT após primeira diferença.

\begin{tabular}{ccc}
\hline Variável & Com intercepto & Com intercepto e com tendência \\
\hline \multirow{2}{*}{ Depósito Total / Ativo Total } & 955,144 & 736,849 \\
& $(0,0000)$ & $(0,0000)$ \\
\hline
\end{tabular}

Nota: p-valor entre parênteses. 


\subsection{Os determinantes das vendas de direitos creditórios}

Na Tabela 5 estão dispostos os resultados da estimação do modelo logit para a equação (1), a qual tem como variável dependente dummy referente à realização de cessões (vendas) de direitos creditórios.

Tabela 5 - Resultados do Logit referente às vendas de direitos creditórios

\begin{tabular}{|c|c|c|c|}
\hline Variável & $\begin{array}{c}\text { Amostra } \\
\text { total }\end{array}$ & $\begin{array}{l}\text { Bancos } \\
\text { grandes }\end{array}$ & $\begin{array}{l}\text { Demais } \\
\text { bancos }\end{array}$ \\
\hline \multirow{2}{*}{$\Delta(\mathbf{D e p} / \mathrm{AT})$} & $-0,4438$ & $-14,5239$ & 0,7727 \\
\hline & $(0,7123)$ & $(0,0525)^{*}$ & $(0,5598)$ \\
\hline \multirow{2}{*}{ Crescimento da carteira de crédito } & 0,0002 & $-0,1988$ & 0,0014 \\
\hline & $(0,9852)$ & $(0,8801)$ & $(0,9113)$ \\
\hline \multirow{2}{*}{$\begin{array}{l}\text { Receitas não intermediação financeira / Receitas } \\
\text { de intermediação financeira }\end{array}$} & 0,0019 & 0,0038 & $-0,0024$ \\
\hline & $(0,1809)$ & $(0,5932)$ & $(0,5579)$ \\
\hline \multirow{2}{*}{ ROE } & $-0,0437$ & 1,5993 & $-0,0879$ \\
\hline & $(0,3871)$ & $(0,6045)$ & $(0,2032)$ \\
\hline \multirow{2}{*}{ Índice de Basileia } & $-0,0560$ & $-0,1886$ & $-0,0399$ \\
\hline & $(0,0000)^{* * *}$ & $(0,0002)^{* * *}$ & $(0,0000)^{* * *}$ \\
\hline \multirow{2}{*}{ Z-Score } & 0,0051 & 0,0175 & 0,0035 \\
\hline & $(0,0000)^{* * *}$ & $(0,0007)^{* * *}$ & $(0,0029)^{* * *}$ \\
\hline \multirow{2}{*}{ PCLD / Carteira de Crédito } & $-0,7734$ & $-36,0129$ & 0,3101 \\
\hline & $(0,2864)$ & $(0,0000)^{* * *}$ & $(0,7396)$ \\
\hline \multirow{2}{*}{ Tipo de Controle Acionário } & 0,8887 & 1,2639 & 0,6073 \\
\hline & $(0,0000) * * *$ & $(0,0002) * * *$ & $(0,0012) * * *$ \\
\hline Log-verossimilhança & $-1177,336$ & $-173,9431$ & $-855,1854$ \\
\hline Estatística LR & $213,6454 * * *$ & $73,21829 * * *$ & $97,07478 * * *$ \\
\hline Pseudo $\mathbf{R}^{2}$ & 0,08319 & 0,173872 & 0,053708 \\
\hline
\end{tabular}

Fonte: elaborada pelo autor.

Notas: (1) p-valor entre parênteses. *** $\mathrm{p}<0,01$; ** $\mathrm{p}<0,05 ; * \mathrm{p}<0,10$. (2) Todas as variáveis defasadas em 1 período.

O coeficiente da razão Dep/AT se apresentou significante apenas para a amostra de bancos grandes. O sinal é negativo, em linha com o esperado para os bancos cedentes e consistente com os resultados encontrados nos trabalhos de Affinito e Tagliaferri (2010, p. 195) e de Ribeiro e Schiozer (2014, p. 533) - similar a este inclusive quanto à baixa significância -, refletindo-se a ideia de que bancos com maior disponibilidade de 
financiamento via depósitos têm menor probabilidade e, portanto, menor propensão à liquidação de parte de suas carteiras de crédito, podendo manter as operações em carteira até o vencimento.

O Índice de Basileia apresentou coeficiente negativo e significante, permitindo a interpretação de que quanto menor o nível de capital regulatório, maior a probabilidade de os bancos venderem suas operações de crédito. O mesmo resultado foi encontrado na pesquisa de Affinito e Tagliaferri (2010, p. 196).

Tal resultado deve ser analisado com cautela, entretanto, pois é fato que os bancos brasileiros costumam operar com uma significativa folga de capital em relação ao mínimo regulatório. Enquanto a Resolução $\mathrm{CMN}^{\circ}{ }^{\circ} 4.193$, de $1^{\circ}$ de março de 2013, determinava como sendo $11 \%$ o mínimo a ser observado pelos bancos brasileiros até dezembro de 2015 , e $9,875 \%$ no primeiro semestre de 2016, a média do Índice de Basileia no período analisado é bastante superior, sendo de aproximadamente 39\% para a amostra total desta pesquisa.

Dessa forma, embora os resultados dos coeficientes estejam alinhados com o preconizado na literatura para a hipótese de arbitragem de capital regulatório, no sentido de que os bancos cedentes seriam aqueles próximos ao limite mínimo de capital regulatório, a realidade dos bancos brasileiros não mostra de forma inequívoca uma necessidade desse tipo de ação, de maneira que o resultado pode ser melhor avaliado posteriormente, mediante os resultados do modelo tobit.

Os coeficientes positivos e significantes para o Z-Score constituem evidências de que, no Brasil, os bancos que apresentam menor risco, quando considerado de uma maneira geral, têm maior propensão a se desfazerem de parte de suas operações de crédito.

A variável PCLD/carteira de crédito, por sua vez, apresentou sinal negativo, embora com significância apenas quando tomadas a base contendo somente os bancos grandes. Sua interpretação, entretanto, está em consonância com a do Z-Score, pois, considerado o risco de crédito somente, constata-se, também, uma relação inversa entre risco e cessão de direitos creditórios. O mesmo resultado foi encontrado por Farruggio e Uhde (2015, p. 19). A explicação dos autores para tanto está no fato de que, aos bancos cujas carteiras de crédito são notadamente mais arriscadas, se impõe a necessidade de oferecerem garantias, implícitas ou explícitas, significativamente maiores, dificultando ou desestimulando, portanto, as vendas de operações de crédito. Bancos com perfil menos arriscado, portanto, encontram maior facilidade de encontrar compradores para seus ativos. 
Destaque-se, todavia, a disparidade de resultados encontrados na literatura no que concerne ao quesito risco. Haubrich e Thomson (1996, p. 150), bem como CardoneRiportella, Samaniego-Medina \& Trujillo-Ponce (2010, p. 2646), não encontram evidência significante de uma relação entre risco e cessões. Por sua vez, embora tenham utilizado variável diferente das deste trabalho para verificação da relação entre cessão de direitos creditórios e risco, Affinito e Tagliaferri (2010, p. 196) encontram evidências de que bancos com maior risco de crédito apresentam maior propensão a se desfazerem de parte de suas carteiras.

Quanto ao Tipo de Controle Acionário, a variável se apresentou também significante e com sinal positivo, confirmando que os bancos públicos apresentam, proporcionalmente, propensão à venda de operações de crédito no mercado secundário relativamente maior do que os bancos de controle privado.

As variáveis Crescimento da Carteira de Crédito, Receitas não Intermediação sobre Receitas de Intermediação Financeira e ROE não apresentaram significância estatística para qualquer das sub-amostras analisadas conforme modelo para as vendas de direitos creditórios.

Em suma, há, portanto, evidências no sentido de que, no mercado brasileiro, há maior probabilidade de realização de vendas de direitos creditórios por parte dos bancos que encontram restrição no financiamento por capital de terceiros - ressaltando-se que tal resultado só pôde ser observado entre os bancos grandes -, que dispõem de menor folga de capital regulatório, e que apresentam perfil de risco menos elevado.

Ademais, o controle público das instituições também se mostrou positivamente relacionado com a maior propensão às vendas de créditos. Fatores relacionados à rentabilidade e à diversificação das atividades bancárias, por outro lado, não apresentaram quaisquer indícios de relação com a realização de cessões de crédito.

\subsection{Os determinantes das compras de direitos creditórios}

No que concerne à perspectiva dos cessionários nas operações de cessão, constam da Tabela 6 os resultados da estimação em logit para identificação dos determinantes da participação dos bancos na posição compradora de direitos creditórios. 
Tabela 6 - Resultados do Logit referente às compras de direitos creditórios

\begin{tabular}{|c|c|c|c|}
\hline Variável & $\begin{array}{c}\text { Amostra } \\
\text { total }\end{array}$ & $\begin{array}{l}\text { Bancos } \\
\text { grandes }\end{array}$ & $\begin{array}{l}\text { Demais } \\
\text { bancos }\end{array}$ \\
\hline \multirow{2}{*}{$\Delta(\mathbf{D e p} / \mathbf{A T})$} & $-2,9314$ & $-1,3652$ & $-2,5891$ \\
\hline & $(0,0012) * * *$ & $(0,0399)^{* *}$ & $(0,0059) * * *$ \\
\hline \multirow{2}{*}{ Crescimento da carteira de crédito } & $-0,0288$ & 0,8074 & $-0,0317$ \\
\hline & $(0,5700)$ & $(0,2081)$ & $(0,5730)$ \\
\hline \multirow{2}{*}{$\begin{array}{l}\text { Receitas não intermediação financeira / Receitas } \\
\text { de intermediação financeira }\end{array}$} & 0,0017 & 0,0125 & 0,0000 \\
\hline & $(0,2500)$ & $(0,3272)$ & $(0,9936)$ \\
\hline \multirow{2}{*}{ ROE } & 0,1291 & 0,7316 & 0,0718 \\
\hline & $(0,3646)$ & $(0,8077)$ & $(0,3716)$ \\
\hline \multirow{2}{*}{ Índice de Basileia } & $-0,0665$ & $-0,2241$ & $-0,0564$ \\
\hline & $(0,0000)^{* * *}$ & $(0,0000)^{* * *}$ & $(0,0000) * * *$ \\
\hline \multirow{2}{*}{ Z-Score } & 0,0057 & 0,0109 & 0,0053 \\
\hline & $(0,0000)^{* * *}$ & $(0,0147)^{* *}$ & $(0,0000) * * *$ \\
\hline \multirow{2}{*}{ PCLD / Carteira de Crédito } & $-1,4586$ & $-3,6265$ & $-1,3515$ \\
\hline & $(0,0069)^{* * *}$ & $-0,4893$ & $(0,0138)^{* *}$ \\
\hline \multirow{2}{*}{ Tipo de Controle Acionário } & $-0,6287$ & $-1,0305$ & $-1,0087$ \\
\hline & $(0,0000) * * *$ & $(0,0009) * * *$ & $(0,0000) * * *$ \\
\hline Log-verossimilhança & $-1718,913$ & $-182,3454$ & $-1454,11$ \\
\hline Estatística LR & $381,5373 * * *$ & $55,90017 * * *$ & $291,3992 * * *$ \\
\hline Pseudo $\mathbf{R}^{2}$ & 0,099896 & 0,132909 & 0,091073 \\
\hline
\end{tabular}

Fonte: elaborada pelo autor.

Notas: (1) p-valor entre parênteses. $* * * \mathrm{p}<0,01$; ** $\mathrm{p}<0,05$; $* \mathrm{p}<0,10$. (2) Todas as variáveis defasadas em 1 período.

A variável Dep/AT resultou negativa e significante para as três especificações de modelo. Destaque-se que, no modelo estimado para os cedentes, a variável apresentou o mesmo sinal, ainda que significante apenas para os bancos grandes. Isso permite inferir que uma maior disponibilidade de depósitos reduz a propensão de que os bancos atuem no mercado secundário de créditos em qualquer que seja a posição. Enquanto bancos com facilidade de captação via depósitos não precisam se desfazer de ativos com vistas ao seu financiamento, também não apresentam propensão ao aproveitamento de tais recursos na compra de operações de crédito.

Em princípio, o coeficiente negativo para o Índice de Basileia indica que, quanto maior o montante de capital regulatório dos bancos, menor a probabilidade de que comprem direitos creditórios. Conforme destacado na análise para os cedentes, a interpretação desse 
resultado deve ser realizada levando-se em consideração que os bancos brasileiros costumeiramente praticam estratégia bastante conservadora no que diz respeito à manutenção de capital regulatório.

Quanto às métricas de risco, novamente, enquanto o Z-score se apresentou positivamente relacionado com as compras de operações de crédito, o coeficiente da variável PCLD / Carteira de Crédito resultou negativo. Quanto a esta, entretanto, cabe o destaque de não ter apresentado significância estatística para a amostra de bancos grandes, enquanto na análise dos cedentes, a não significância se deu na amostra dos demais bancos. Em comparação com os estudos anteriores, cabe ressaltar que Haubrich e Thomson (1996, p. 152) e Demsetz (2000, p. 213) não identificam de forma significante, também entre os bancos cessionários, uma relação positiva entre risco e a propensão de comprar operações de crédito.

Os resultados desta pesquisa, entretanto, indicam maior propensão dos bancos com perfil menos arriscado também a adquirirem direitos creditórios. Isto rechaça a possibilidade de que bancos com maior apetite a risco e que, portanto, naturalmente apresentem um menor valor para o Z-score ou maior valor para o nível de provisionamento, estejam mais propensos a investirem na aquisição de operações de crédito de terceiros. Tal interpretação, entretanto, deve ser vista com ressalvas para os bancos grandes, dada a já mencionada não significância para a variável PCLD / Carteira de crédito e significância inferior para a variável Z-score.

Assim como no caso da análise para as vendas, mais uma vez os coeficientes para a variável referente ao tipo de consolidação se apresentou com sinal positivo e significante, reforçando a ideia de que instituições integrantes de conglomerados apresentam maior propensão a atuarem no mercado de cessões também como compradores possivelmente fazendo uso dessas operações com o intuito de gerenciar o balanço consolidado do conglomerado. Tal resultado corrobora também os estudos de Haubrich e Thomson (1996, p. 152) e de Demsetz (2000, p. 210).

Sendo assim, constata-se que figuram entre os cessionários no mercado brasileiro os bancos com maior capacidade de financiamento com recursos próprios e menor disponibilidade de depósitos, os bancos que apresentam menores índices de capital regulatório e perfil menos arriscado. Apresentam também maior propensão à atuação como compradores os bancos públicos e, assim como no caso das vendas de direitos creditórios, não se verificou influência de fatores relacionados à rentabilidade ou à diversificação das atividades das instituições sobre a decisão de comprar operações de crédito. 


\subsection{O impacto das cessões sobre as receitas de intermediação financeira dos bancos cedentes}

Analisados os determinantes da decisão de entrada ou não no mercado de cessões de direitos creditórios, passamos agora à análise da magnitude do impacto das cessões sobre as receitas de intermediação financeira dos bancos que optaram por entrar no mercado de cessões vendendo operações de crédito. Os resultados do modelo tobit estimado com essa finalidade estão dispostos na Tabela 7.

Tabela 7 - Resultados do Tobit referente às receitas com cessão de direitos creditórios.

\begin{tabular}{|c|c|c|c|}
\hline Variável & $\begin{array}{c}\text { Amostra } \\
\text { total }\end{array}$ & $\begin{array}{l}\text { Bancos } \\
\text { grandes }\end{array}$ & $\begin{array}{l}\text { Demais } \\
\text { bancos }\end{array}$ \\
\hline \multirow{2}{*}{$\Delta(\mathbf{D e p} / \mathrm{AT})$} & $-0,0120$ & $-0,0370$ & 0,0165 \\
\hline & $(0,6634)$ & $(0,0346)^{* *}$ & $(0,6675)$ \\
\hline \multirow{2}{*}{ Crescimento da carteira de crédito } & $-0,0001$ & $-0,0023$ & 0,0000 \\
\hline & $(0,8152)$ & $(0,4624)$ & $(0,9487)$ \\
\hline \multirow{2}{*}{$\begin{array}{l}\text { Receitas não intermediação financeira / Receitas } \\
\text { de intermediação financeira }\end{array}$} & 0,0000 & 0,0000 & $-0,0001$ \\
\hline & $(0,0000) * * *$ & $(0,0000) * * *$ & $(0,1545)$ \\
\hline \multirow{2}{*}{ ROE } & $-0,0051$ & 0,0097 & $-0,0063$ \\
\hline & $(0,0000)^{* * * *}$ & $(0,2355)$ & $(0,0000)^{* * *}$ \\
\hline \multirow{2}{*}{ Índice de Basileia } & $-0,0013$ & $-0,0003$ & $-0,0013$ \\
\hline & $(0,0000)^{* * *}$ & $(0,0007)^{* * *}$ & $(0,0000)^{* * *}$ \\
\hline \multirow{2}{*}{ Z-Score } & 0,0001 & 0,0000 & 0,0001 \\
\hline & $(0,0030) * * *$ & $(0,0010)^{* * *}$ & $(0,0105)^{* *}$ \\
\hline \multirow{2}{*}{ PCLD / Carteira de Crédito } & $-0,0103$ & $-0,0626$ & 0,0144 \\
\hline & $(0,5454)$ & $(0,0007)^{* * *}$ & $(0,5956)$ \\
\hline \multirow{2}{*}{ Tipo de Controle Acionário } & 0,0191 & 0,0032 & 0,0169 \\
\hline & $(0,0000) * * *$ & $(0,0004) * * *$ & $(0,0189)^{* *}$ \\
\hline Log-verossimilhança & $-123,7658$ & 482,9163 & $-256,1032$ \\
\hline
\end{tabular}

Fonte: elaborada pelo autor.

Notas: (1) p-valor entre parênteses. $* * * \mathrm{p}<0,01$; $* * \mathrm{p}<0,05$; $* \mathrm{p}<0,10$. (2) Todas as variáveis defasadas em 1 período.

A variável Dep/AT, referente ao financiamento com capital de terceiros, se apresentou significante apenas para os bancos grandes, e com sinal negativo. Tal achado vai ao encontro dos resultados de Bannier e Hänsel (2008) e de Farruggio e Uhde (2015, p. 19), os quais constataram que, quanto maiores e menos líquidos os bancos, não só é maior a propensão a 
se desfazerem de parte de suas operações de crédito como também é maior o volume de ativos vendidos. Neste caso, entre os bancos cedentes constata-se que os que apresentam menor capacidade de financiamento via depósitos são exatamente os que auferem as maiores receitas com cessão em relação ao total de suas receitas de intermediação.

Assim como no trabalho de Affinito e Tagliaferri (2010, p. 198), a variável relacionada à diversificação da atividade bancária, Receitas não relacionadas à Intermediação Financeira sobre Receitas de Intermediação Financeira, apresentou coeficiente positivo e significante. Neste trabalho, o resultado se aplica aos bancos cedentes na amostra total e na amostra de bancos grandes, dando suporte a ideia de que, quanto maior a diversificação de atividade dos bancos, maior o resultado auferido com as vendas de direitos creditórios em relação ao montante das receitas de intermediação. O resultado vai também ao encontro de Casu, Clare, Sarkysian e Thomas (2013, p. 1639). Isso sugere que os bancos nos quais a intermediação financeira tem um peso menor em termos do volume total de receitas geradas pela instituição são também os que cedem mais de sua carteira de crédito mostrando que as instituições com maior concentração de atividades em intermediação apresentam maior tendência a manterem as operações de crédito até o vencimento.

A variável ROE apresentou coeficiente com sinal negativo e significante, à exceção da base composta apenas pelos bancos grandes, indicando que, quanto maior a rentabilidade do banco, menor a participação das receitas com cessões na composição das receitas de intermediação financeira. Nota-se, portanto, que a busca por maior rentabilidade não serve de justificativa para o engajamento dos bancos no mercado de cessões na posição de cedentes. Tal resultado converge também para o encontrado por Affinito e Tagliaferri (2010, p. 196), que identificam haver uma relação negativa entre a rentabilidade dos bancos e as vendas de direitos creditórios, mas diverge de Farruggio e Uhde (2015, p. 21) no que diz respeito ao sinal.

O coeficiente do Índice de Basileia se apresentou negativo e significante em todas as amostras, indicando que, quanto menor o volume de capital regulatório mantido pelos bancos, maiores suas receitas com cessão de créditos. O resultado está alinhado com os achados de Affinito e Tagliaferri (2010, p. 196) e de Ribeiro e Schiozer (2014, p. 530), os quais concluíram, analogamente, que um menor montante de capital regulatório induz uma maior realização de vendas de operações de crédito. Sendo assim, embora, conforme ressalvado anteriormente, os bancos brasileiros trabalhem com margens consideráveis no que diz respeito a esse índice, quando considerado apenas o universo dos cedentes, a ideia 
de que bancos com menor folga de capital regulatório tendem a ceder mais - ou, no caso, tendem a auferir maiores receitas com as cessões no total das receitas de intermediação - é válida.

Pela variável PCLD sobre Carteira de Crédito, verificou-se uma relação negativa e significante com as cessões apenas entre os bancos grandes. Tal resultado, em princípio, indica que os bancos com maior exposição ao risco de crédito são os que menos auferem receitas com a venda de direitos creditórios. O mesmo resultado é encontrado na pesquisa de Farruggio e Uhde (2015, p. 19), ressaltando-se, portanto, o argumento de que, nas operações de cessão, bancos que apresentam maior risco são obrigados a oferecer maiores garantias, implícitas ou explícitas, a fim de se reduzir assimetrias de informação com os compradores, o que acaba não só desestimulando às cessões como também reduzindo as receitas com tais operações quando realizadas.

Por sua vez, o coeficiente do Z-Score, apesar de ter apresentado significância semelhante ao da variável PCLD sobre Carteira de Crédito, mostrou sinal positivo. A mesma relação contrária de sinais foi encontrada por Farruggio e Uhde (2015, p. 23), apesar de o ZScore não ter se mostrado significante naquela pesquisa. Dessa forma, mais uma vez se tem evidência de que no mercado de cessões prevalece a atuação dos bancos de menor risco.

O controle público também se mostrou significativa e positivamente relacionado com as cessões. É possível inferir que bancos públicos não só apresentam maior propensão à realização de vendas de direitos creditórios, conforme visto anteriormente, como também tendem a registrar proporcionalmente maiores volumes de receitas com as cessões em relação aos seus resultados de intermediação financeira.

Portanto, da perspectiva da relevância das receitas com as vendas de direitos creditórios na composição das receitas de intermediação financeira dos bancos cedentes, verifica-se, primeiramente, uma discrepância entre os bancos de grande porte e os demais no que diz respeito às fontes de financiamento à disposição. Enquanto apenas entre os bancos grandes a restrição de depósitos se mostrou determinante para a elevação das receitas com cessão, para as demais instituições, o mesmo efeito é determinado por uma maior disponibilidade de financiamento por capital próprio. A maior diversificação de atividades é característica dos bancos grandes com as maiores receitas de cessão, enquanto entre os bancos de menor porte o fator rentabilidade se mostrou mais relevante.

Entre os demais fatores analisados, os resultados foram consistentes para com os achados dos modelos anteriormente estimados. Bancos com menor folga de capital, com 
perfil menos arriscado e públicos apresentaram propensão a comporem maior parte de suas receitas de intermediação financeira com as receitas decorrentes de operações de cessão.

\subsection{O impacto das cessões sobre as despesas com intermediação financeira dos bancos cessionários}

Por fim, tem-se na Tabela 8 os resultados para a análise dos fatores mais relevantes no que concerne à participação das cessões de direitos creditórios na composição das despesas com intermediação financeira dos bancos cessionários.

Tabela 8 - Resultados do Tobit referente às despesas com aquisição de direitos creditórios.

\begin{tabular}{lccc}
\hline \multicolumn{1}{c}{ Variável } & $\begin{array}{c}\text { Amostra } \\
\text { total }\end{array}$ & $\begin{array}{c}\text { Bancos } \\
\text { grandes }\end{array}$ & $\begin{array}{c}\text { Demais } \\
\text { bancos }\end{array}$ \\
\hline (Dep/AT) & 0,1267 & 0,0840 & 0,1308 \\
& $(0,6872)$ & $(0,1573)$ & $(0,6841)$ \\
Crescimento da carteira de crédito & $-0,0001$ & $-0,0130$ & $-0,0001$ \\
& $(0,7088)$ & $(0,0477)^{* *}$ & $(0,7536)$ \\
Receitas não intermediação financeira / Receitas & 0,0000 & 0,0000 & 0,0000 \\
de intermediação financeira & $(0,5581)$ & $(0,2242)$ & $(0,6298)$ \\
& & & 0,0014 \\
ROE & 0,0016 & $-0,1249$ & $(0,5070)$ \\
Índice de Basileia & $(0,4571)$ & $(0,0103)^{* *}$ & \\
& & & 0,0000 \\
Tipo de Controle Acionário & 0,0000 & $-0,0017$ & $(0,5666)$ \\
\hline Log-verossimilhança & $(0,5774)$ & $(0,0012)^{* * *}$ & \\
\hline FCLD / Carteira de Crédito & & & 0,0001 \\
& 0,0001 & 0,0001 & $(0,6643)$ \\
& $(0,6560)$ & $(0,3891)$ & $-0,1224$ \\
& $-0,1239$ & $-0,0428$ & $(0,5492)$ \\
& $(0,5442)$ & $(0,1346)$ & $-8460,023$ \\
\hline
\end{tabular}

Fonte: elaborada pelo autor.

Notas: (1) p-valor entre parênteses. $* * * \mathrm{p}<0,01$; ** $\mathrm{p}<0,05 ; * \mathrm{p}<0,10$. (2) Todas as variáveis defasadas em 1 período.

O primeiro fator de destaque a ser analisado é o fato de que, de uma maneira geral, nenhuma das variáveis apresentou significância quando consideradas as amostras total e com a exclusão dos bancos grandes. Apenas para os bancos de maior porte as variáveis 
empregadas mostraram exercer alguma influência na magnitude das despesas com cessão no montante das despesas de intermediação financeira.

No que concerne às variáveis relacionadas às alternativas de financiamento/liquidez, somente o Crescimento da Carteira de Crédito apresentou significância estatística, e apenas ao nível de $10 \%$. O sinal do coeficiente é negativo, indicando que um aumento dessa variável se relaciona de forma inversa ao montante despendido pelos bancos com a aquisição de novas operações de crédito.

Tal achado suporta a ideia de que os bancos grandes, ao originarem diretamente determinados tipos de operações de crédito, não teriam mais a necessidade de adquiri-los de outras instituições para composição de carteira.

Analisando tal variável na perspectiva dos cedentes, Affinito e Tagliaferri (2010, p. 198), Casu, Clare, Sarkysian e Thomas (2013, p. 1639) e Farruggio e Uhde (2015, p. 19), encontraram sinal positivo, concluindo que, em períodos de maior demanda por novas concessões de crédito, as cessões também tendem a aumentar, como forma de obtenção de financiamento pelos bancos para a realização de novas operações mais rentáveis. Todavia, o que o resultado ora encontrado no contexto dos cessionários sugere é que, entre os bancos brasileiros, há uma tendência a se realizar maiores despesas na aquisição de operações de crédito originadas por terceiros quando o crescimento da carteira de crédito é menor, isto é, em um contexto de menor número de originações de novas operações de crédito, os bancos apresentam tendência a despender maiores montantes na compra, no mercado secundário, de operações de crédito já contratadas.

O ROE também resultou com sinal negativo, indicando que os bancos menos rentáveis são também os que tendem a despender mais proporcionalmente com a aquisição de direitos creditórios em relação às suas despesas de intermediação financeira, o que sugere que bancos com performance inferior em termos de retornos sobre o patrimônio líquido podem buscar na aquisição de operações originadas por outras instituições a composição de suas carteiras de crédito com ativos mais rentáveis. Tal resultado pode ser confrontado e compreendido em linha com os de Affinito e Tagliaferri (2010, p. 196), que, analisando da perspectiva dos cedentes, constataram que, quanto mais rentáveis os bancos, menores eram as chances de que se engajassem na venda de seus direitos creditórios, ressaltando-se que a mesma relação foi encontrada nesta pesquisa quando da análise dos cedentes.

O Índice de Basileia apresentou forte significância e sinal negativo. Todavia, considerando o contexto brasileiro, parece equivocado interpretar tal resultado como 
indicativo de que uma menor folga de capital levaria a uma tendência de os bancos despenderem mais com a aquisição de direitos creditórios, de forma que a arbitragem de capital carece de consistência no contexto dos cessionários.

As demais variáveis não apresentaram significância. Verifica-se, portanto, em relação aos montantes despendidos na aquisição de direitos creditórios em relação aos totais de despesas de intermediação financeira, que as alternativas de financiamento, a diversificação de atividades e o risco não são fatores relevantes na propensão de os bancos investirem relativamente mais na compra de direitos creditórios. Apenas a rentabilidade e o índice de capital regulatório mostraram-se significantes, tendo relação inversa com os maiores dispêndios com as cessões.

\section{CONSIDERAÇÕES FINAIS}

Esta pesquisa buscou identificar quais os determinantes para as cessões de direitos creditórios no setor bancário brasileiro sob as perspectivas tanto do lado da oferta, ou seja, dos cedentes, quanto do lado da demanda, o dos cessionários. Para tanto, revisitou a literatura, a fim de levantar quais os principais fatores apontados como possíveis justificativas econômico-financeiras para tais transações, bem como outros trabalhos empíricos que as tenham testado anteriormente, seja no contex to nacional ou no de mercados estrangeiros.

Para contextualização da pesquisa, procedeu-se também à revisão do marco regulatório concernente ao tema, desde as primeiras normas exaradas com vistas ao estabelecimento de regras para a realização das operações, até o arcabouço ora vigente. Tal análise normativa contribuiu tanto para melhor compreensão de como as operações de cessão são registradas pelos bancos e impactam seu resultado quanto para identificação, nos dados publicados pelo Banco Central do Brasil, das possibilidades de construção de variáveis passíveis de utilização nos testes estatísticos.

O trabalho visou contribuir com a literatura referente ao tema sobretudo em três aspectos. Primeiramente, são escassos os trabalhos que tenham buscado identificar quais os fatores que influenciam a decisão de os bancos entrarem no mercado de cessão na posição de compradores. A maior parte das pesquisas anteriores se limita a analisar a perspectiva dos cedentes. Acredita-se que isso se deve ao maior número de transações registradas, já que as vendas de direitos creditórios podem ser feitas não só para outros bancos como também para 
outros tipos de instituições. Todavia, o fato de parte dos bancos brasileiros também figurarem entre os que adquirirem operações de crédito contratadas por terceiros e a possibilidade de avaliação de seu comportamento a partir de informações publicadas pelo órgão supervisor ofereciam oportunidade de complementação das pesquisas anteriores que tiveram o mercado nacional como cenário.

Uma segunda contribuição a ser destacada diz respeito ao fato de que as pesquisas anteriores se focaram em fatores específicos que de alguma forma podiam guardar relação com as cessões, como a restrição de fontes de financiamento ou o gerenciamento de risco das instituições bancárias. Todavia, conforme se mostrou na revisão da literatura, haviam outros possíveis determinantes aventados anteriormente em pesquisas estrangeiras, tanto teóricas quanto empíricas, que careciam ainda de teste no âmbito nacional, tais como a busca por rentabilidade e diversificação dos bancos e a arbitragem de capital regulatório. A inclusão desses fatores no presente trabalho permitiu, portanto, uma avaliação mais ampla dos fatores determinantes das operações no mercado local de cessões.

Ademais, a realização do presente estudo com base em dados coletados em período mais recente do que os de pesquisas anteriores propiciou que se tivesse, como pano de fundo, um contexto normativo e contábil diferenciado. Enquanto outros trabalhos foram realizados com dados compilados antes da edição da Resolução CMN n 3.533, de 2008, ora vigente, limitou-se, nesta pesquisa, à análise do período posterior à publicação dessa norma. A diferença consiste no fato de que tal regulamentação inseriu importantes alterações na forma de contabilização das operações de cessão de direitos creditórios, de forma que mesmo a análise dos determinantes já antes explorados se mostraram válidas, por permitir que as conclusões de trabalhos anteriores pudessem ter base de comparação no contexto normativo/contábil atual.

No que concerne aos resultados, pode-se concluir que todos os quatro fatores examinados neste estudo apresentaram relevância sobre ao menos algum aspecto da participação dos bancos no mercado de cessões de direitos creditórios, seja na decisão de os bancos realizarem ou não esse tipo de operação, seja no volume financeiro movimentado com as operações em relação ao resultado total de intermediação financeira.

$\mathrm{O}$ exame das fontes de financiamento e necessidades de liquidez dos bancos mostrou que os bancos com maior restrição na captação de depósitos apresentam maior propensão a venderem direitos creditórios, conforme preconizado na literatura, e também auferem proporcionalmente um maior volume de receitas com as cessões em relação às suas receitas 
de intermediação. Já quando se volta à capacidade de financiamento dos bancos com recursos internos, esta se mostrou relevante, sobretudo, na determinação de os bancos atuarem na posição de cessionários, mas não se mostrou relacionada com os volumes financeiros despendidos nas operações de compra.

A diversificação e a rentabilidade dos bancos não se mostraram determinantes para a decisão de os bancos entrarem no mercado de cessões. Entretanto, considerando as instituições que de fato já atuam nesse mercado, seja como cedentes ou cessionários, tais fatores apresentaram relativa relevância nos montantes financeiros movimentados. Enquanto verificou-se que a maior diversificação de atividades, característica sobretudo entre os bancos grandes, influi em maiores proporções das receitas com cessões na composição das receitas de intermediação financeira, uma menor rentabilidade dos bancos se mostrou determinante tanto para que os bancos de menor porte apresentassem proporcionalmente maiores montantes financeiros movimentados com as cessões na composição de suas receitas de intermediação quanto para as maiores despesas do lado dos bancos grandes.

O Índice de capital regulatório se mostrou significante em todos os modelos avaliados. Constatou-se maior atuação dos bancos no mercado de cessões quanto menores seus Índices de Basileia, seja como cedentes ou cessionários. Embora tal comportamento esteja de acordo com o esperado pela literatura no caso das operações de venda, do ponto de vista econômicofinanceiro o resultado surpreende em relação aos cessionários. Faz-se possível apenas ressaltar o fato de que os bancos brasileiros atuam, na média, com elevadas folgas de capital em relação ao mínimo regulatório, de forma que mesmo os bancos que apresentam relativamente os menores Índices de Basileia ainda não se encontram, necessariamente, pressionados em relação ao cumprimento das normas e em posição de terem que se desfazer de ativos.

Na perspectiva do risco das instituições, à exceção dos montantes despendidos pelos cessionários nas operações de compra, em todas as outras análises as variáveis se mostraram significantes, e de maneira similar. No Brasil, as atividades de cessão de direitos creditórios são realizadas sobretudo por bancos de perfil menos arriscado. Portanto, embora casos específicos possam sinalizar o contrário, o fato é que, dentro da amostra considerada, não se encontraram evidências de que a transferência de operações de menor qualidade creditícia seja prática comum entre os cedentes, tampouco que haja um perfil de maior apetite a risco entre os bancos cessionários. 
Ainda em relação aos resultados, cabe destacar que, em todas as análises, constatouse que bancos integrantes de conglomerado e bancos públicos apresentam maior propensão a atuar no mercado de cessões e a fazê-lo com maior relevância dentro de suas atividades de intermediação financeira.

Por fim, faz-se também necessário mencionar as limitações da pesquisa. O mercado de cessões de direitos creditórios apresenta ainda uma série de características que não puderam ser avaliadas no presente estudo devido à indisponibilidade de dados de acesso público. Embora tenha sido relatada na revisão da regulamentação nacional a distinção entre operações realizadas com transferência substancial de riscos e benefícios e operações com retenção substancial de riscos e benefícios, os dois tipos não puderam ser avaliados separadamente. Muito embora tal procedimento possa dar uma visão mais clara dos determinantes que levam os bancos a fazerem vendas definitivas, frente aos motivadores das operações com característica mais similar a empréstimos com garantias, as informações publicadas pelo $\mathrm{BCB}$ referentes às receitas e despesas com cessões de crédito são compostas por aglutinações de contas do COSIF que contém, somadas, operações com as duas características, sendo indissociáveis nas bases de livre acesso.

Atualmente, os montantes financeiros referentes às operações cedidas também não são dados livremente acessíveis. Portanto, embora tenha sido possível auferir os valores apurados com as receitas e despesas com as cessões e sua participação na composição de receitas e intermediação financeira, seria importante traçar uma noção mais exata dos fluxos de cessões em relação aos montantes das carteiras de crédito dos bancos.

Quanto aos determinantes explorados no estudo, cabe a ressalva de que certamente não são exaustivos em relação aos já apontados pela literatura. Entre pesquisas mais recentes, encontra-se, por exemplo, análise de possíveis incentivos de cunho tributário para a realização de cessões de direitos creditórios pelos bancos (Han, Park \& Pennacchi, 2015). É possível, portanto, que fatores não aventados no presente estudo de alguma forma também direcionem o mercado brasileiro de cessões.

E mesmo entre os determinantes aqui avaliados, há ainda possibilidades de aprofundamento da análise. Nesse sentido, destaca-se o fator diversificação. Embora tenhase investigado nesta pesquisa a busca dos bancos por diversificação de atividades, não foi possível investigar tipo mais específico de diversificação, isto é, concernente à composição das carteiras de crédito. Dessa forma, faz-se ainda oportuno analisar a sensibilidade das 
operações de cessão a diferentes tipos de ativo - financiamento de veículos, financiamentos habitacionais, empréstimos consignados, outros - e por diferentes setores econômicos.

Dessa forma, as próprias limitações desta pesquisa podem ser apontadas como possibilidades de pesquisas futuras, sendo importante destacar, todavia, que, para sua realização, impõe-se a necessidade de acesso a dados que, por ora, são restritos aos órgãos reguladores e à Câmara de Cessão de Créditos (C3).

\section{REFERÊNCIAS}

Affinito, M., \& Tagliaferri, E. (2010). Why Do (or Did?) Banks Securitize Their Loans? Evidence from Italy. Journal of Financial Stability, 6, 189-202.

Ahn, J. H., \& Breton, R. (2014). Securitization, competition and monitoring. Journal of Banking and Finance, 40(1), 195-210. http://doi.org/10.1016/j.jbankfin.2013.11.023

Akerlof, G. a. (1970). The Market for "Lemons": Quality Uncertainty and the Market Mechanism. Quarterly Journal of Economics, 84(3), 488-500. http://doi.org/10.2307/1879431

Albertazzi, U., Eramo, G., Gambacorta, L., \& Salleo, C. (2015). Asymmetric information in securitization: An empirical assessment. Journal of Monetary Economics, 71, 33 49. http://doi.org/10.1016/j.jmoneco.2014.11.002

Altman, E. I., Gande, A., \& Saunders, A. (2010). Bank debt versus bond debt: Evidence from secondary market prices. Journal of Money, Credit and Banking, 42(4), 755767. http://doi.org/10.1111/j.1538-4616.2010.00306.x

An, X., Deng, Y., \& Gabriel, S. a. (2011). Asymmetric information, adverse selection, and the pricing of CMBS. Journal of Financial Economics, 100(2), 304-325. http://doi.org/10.1016/j.jfineco.2010.12.002

Baltagi, H. B. (2008). Econometric Analysis of Panel Data ( $4^{\text {th }}$ ed.). Chichester, West Sussex: John Wiley \& Sons Ltd.

Banco Central do Brasil - BCB. (2005). Ato do Presidente $n^{\circ} 1.095$, de 4 de maio de 2005. Decreta a liquidação extrajudicial do Banco Santos S.A. Recuperado em 5 de outubro, 2016, de

http://www.bcb.gov.br/pre/normativos/busca/normativo.asp?numero=1095\&tipo=Ato $\% 20$ do\%20Presidente $\&$ data $=4 / 5 / 2005$.

Banco Central do Brasil - BCB. (2009). Relatório de Estabilidade Financeira: outubro de 2009. Recuperado em 3 de novembro, 2015, de http://www.bcb.gov.br/?RELESTAB200910. 
Banco Central do Brasil - BCB. (2012a). Relatório de Estabilidade Financeira: março de 2012. Recuperado em 3 de novembro, 2015, de

http://www.bcb.gov.br/?RELESTAB201203.

Banco Central do Brasil - BCB. (2012b). Comunicado no 21.928, de 25 de janeiro de 2012. Divulga autorização para funcionamento da Central de Cessão de Crédito - C3. Recuperado em 5 de outubro, 2016, de http://www.bcb.gov.br/pre/normativos/busca/normativo.asp?numero=21928\&tipo=Co municado\&data=25/1/2012.

Banco Central do Brasil - BCB. (2015). Relatório de Estabilidade Financeira: outubro de 2015. Recuperado em 3 de novembro, 2015, de http://www.bcb.gov.br/?RELESTAB201510.

Banco Central do Brasil - BCB. (2016a). 50 maiores bancos e o consolidado do Sistema Financeiro Nacional. Recuperado em outubro, 2016, de http://www4.bcb.gov.br/top50/port/top50.asp.

Banco Central do Brasil - BCB. (2016b). IF.Data - Dados Selecionados de Entidades Supervisionadas. Recuperado em outubro, 2016, de https://www3.bcb.gov.br/informes/relatorios?lingua=pt

Bannier, C. E., \& Hänsel, D. N. (2008). Determinants of European banks' engagement in loan securitization. Deutsche Bundesbank Discussion Paper Series 2: Banking and Financial Studies, (10). https://ssrn.com/abstract=2794014

Bedendo, M., \& Bruno, B. (2012). Credit risk transfer in U.S. commercial banks: What changed during the 2007-2009 crisis? Journal of Banking and Finance, 36(12), 32603273. http://doi.org/10.1016/j.jbankfin.2012.07.011

Berndt, A., \& Gupta, A. (2009). Moral hazard and adverse selection in the originate-todistribute model of bank credit. Journal of Monetary Economics, 56(5), 725-743. http://doi.org/10.1016/j.jmoneco.2009.04.002

Brooks, C. (2014). Introductory Econometrics for Finance. ( $3^{\text {rd }}$ ed.). New York: Cambridge University Press.

Cantor, R., \& Demsetz, R. (1993). Securitization, loan sales, and the credit slowdown. Federal Reserve Bank of New York Quarterly Review.

Cardone-Riportella, C., Samaniego-Medina, R., \& Trujillo-Ponce, A. (2010). What drives bank securitisation? The Spanish experience. Journal of Banking and Finance, 34(11), 2639-2651. http://doi.org/10.1016/j.jbankfin.2010.05.003

Carlstrom, C. T., \& Samolyk, K. a. (1995). Loan sales as a response to market-based capital constraints. Journal of Banking \& Finance, 19(3-4), 627-646. http://doi.org/10.1016/0378-4266(94)00144-R 
Casu, B., Clare, A., Sarkisyan, A., \& Thomas, S. (2013). Securitization and Bank Performance. Journal of Money, Credit and Banking, 45(8), 1617-1658. http://doi.org/10.1111/jmcb.12064

Conselho Monetário Nacional - CMN. Resolução n 453, de 16 de novembro de 1977 (1977). Dispõe sobre a prestação de garantias, concessão de empréstimos e cessão de créditos pelos bancos de investimento. Brasília, DF. Recuperado em 23 outubro, 2016, de https://www.bcb.gov.br/pre/normativos/busca/downloadNormativo.asp?arquivo=/List s/Normativos/Attachments/40724/Res_0453_v2_L.pdf

Conselho Monetário Nacional - CMN. Resolução n 1.762 , de 26 de janeiro de 2000 (2000). Estabelece condições para a cessão de créditos a sociedades anônimas de objeto exclusivo e a companhias securitizadoras de créditos imobiliários. Brasília, DF. Recuperado em 23 outubro, 2016, de http://www.bcb.gov.br/pre/normativos/busca/downloadNormativo.asp?arquivo=/Lists /Normativos/Attachments/47434/Res_2686_v3_L.pdf

Conselho Monetário Nacional - CMN. Resolução no 2.836, de 30 de maio de 2001 (2001). Altera e consolida normas sobre cessão de créditos. Brasília, DF. Recuperado em 23 outubro, 2016, de http://www.bcb.gov.br/pre/normativos/busca/downloadNormativo.asp?arquivo=/Lists /Normativos/Attachments/47140/Res_2836_v3_L.pdf

Conselho Monetário Nacional - CMN. Resolução n 2.686, de 31 de outubro de 1990 (1990). Programa federal de desregulamentação Decreto $\mathrm{n}^{\circ} .99 .179$, de 15.03 .90 estabelece e consolida normas sobre cessões de crédito entre instituições financeiras e sociedades de arrendamento mercantil. Brasília, DF. Recuperado em 23 outubro, 2016, de http://www.bcb.gov.br/pre/normativos/busca/downloadNormativo.asp?arquivo=/Lists /Normativos/Attachments/44598/Res_1762_v2_L.pdf

Conselho Monetário Nacional - CMN. Resolução no 3.533, de 31 de janeiro de 2008 (2008). Estabelece procedimentos para classificação, registro contábil e divulgação de operações de venda ou de transferência de ativos financeiros. Brasília, DF.

Recuperado em 25 novembro, 2015, de http://www.bcb.gov.br/pre/normativos/busca/normativo.asp?numero=3533\&tipo=Res olu\%C3\%A7\%C3\%A3o\&data=31/01/2008.

Dahiya, S., Puri, M., \& Saunders, A. (2003). Bank Borrowers and Loan Sales: New Evidence on the Uniqueness of Bank Loans. The Journal of Business, 76(4), 563-582. http://doi.org/10.1086/377031

Dell'Ariccia, G. (2001). Asymmetric information and the structure of the banking industry. European Economic Review, 45, 1957-1980. http://dx.doi.org/10.1016/S00142921(00)00085-4

Demsetz, R. S. (2000). Bank loan sales: a new look at the motivations for secondary market activity. The Journal of Financial Research, XXIII(2), 197-222. 
Drucker, S., \& Puri, M. (2009). On loan sales, loan contracting, and lending relationships. The Review of Financial Studies, 22(7), 2635-2672. http://doi.org/10.1093/rfs/hhn067

Farruggio, C., \& Uhde, A. (2015). Determinants of loan securitization in European banking. Journal of Banking and Finance, 56, 12-27.

http://doi.org/10.1016/j.jbankfin.2015.01.015

Ferreira, B. L., \& Lustosa, P. R. B. (2012). O Caso do Banco Panamericano Sob o Ponto de Vista da Ética. Revista Ambiente Contábil, 4(1), 1-16. https://periodicos.ufrn.br/ambiente/article/view/1906

Gande, A., \& Saunders, A. (2012). Are Banks Still Special When There Is a Secondary Market for Loans? Journal of Finance, 67(5), 1649-1684. http://doi.org/10.1111/j.1540-6261.2012.01769.x

Gorton, G. B., \& Pennacchi, G. G. (1995). Banks and loan sales: marketing nonmarketable assets. Journal of Monetary Economics, 35, 389-411.

Greenbaum, S. I., \& Thakor, A. V. (1987). Bank Funding Modes: Securitization versus Deposits. Journal of Banking and Finance, 11, 379-401.

Han, J., Park, K., \& Pennacchi, G. (2015). Corporate Taxes and Securitization. The Journal of Finance, 70(3), 1287-1321. http://doi.org/10.1111/jofi.12157

Haubrich, J. G., \& Thomson, J. B. (1996). Loan Sales, Implicit Contracts, and Bank Structure. Review of Quantitative Finance and Accounting, 7, 137-162.

James, C. (1988). The use of loan sales and standby letters of credit by commercial banks. Journal of Monetary Economics, 22(3), 395-422. http://doi.org/10.1016/0304$\underline{3932(88) 90005-0}$

Jevons, W. S. (1996) [1871]. A Teoria da Economia Política. São Paulo: Nova Cultural.

Keynes, J. M. (1996) [1973]. A Teoria Geral do Emprego, do Juro e da Moeda. São Paulo: Nova Cultural.

Laureano, G. L. (2009). Sale of credit portfolio and risk: the case of financial institutions in Brazil. (Dissertação de mestrado). Fundação Getúlio Vargas, São Paulo. http://bibliotecadigital.fgv.br/dspace/bitstream/handle/10438/4671/61070100623.pdf;j sessionid=476230CD3A50C772F95CEE0BA312A235? sequence $=1$

Lucas, D. J., \& McDonald, R. L. (1992). Bank Financing and Investment Decisions with Asymmetric Information about Loan Quality. The RAND Journal of Economics, 23(1), 86-105. http://www.jstor.org/stable/2555434

Marx, K. (1996)[1867]. O Capital: crítica da economia política. Os Economistas. São Paulo: Nova Cultural. 
Parlour, C. a., \& Plantin, G. (2008). Loan sales and relationship banking. Journal of Finance, 63(3), 1291-1314. http://doi.org/10.1111/j.1540-6261.2008.01358.x

Parlour, C. a., \& Winton, A. (2013). Laying off credit risk: Loan sales versus credit default swaps. Journal of Financial Economics, 107(1), 25-45.

http://doi.org/10.1016/j.jfineco.2012.08.004

Pavel, C., \& Philis, D. (1987). Why commercial banks sell loans: An empirical analysis. Federal Reserve Bank of Chicago Economic Perspectives, 14, 3-14.

Peleias, I. R., Andrade, P. R. M., Alencar, L. B., \& Weffort, E. F. J. (2012). Banco Panamericano - um problema de governança corporativa? Revista Gestão Organizacional, 5(1), 117-129. https://bell.unochapeco.edu.br/revistas/index.php/rgo/article/view/1251/687

Pennacchi, G. G. (1988). Loan Sales and the Cost of Bank Capital. Journal of Finance. http://doi.org/10.2307/2328466

Purnanandam, A. (2011). Originate-to-distribute model and the subprime mortgage crisis. Review of Financial Studies, 24(6), 1881-1915. http://doi.org/10.1093/rfs/hhq106

Ribeiro, F. V. F., \& Schiozer, R. F. (2014). Cessão de Crédito e Restrição De Capital: Um estudo com bancos brasileiros. Revista de Administração de Empresas, 54(5), 521536.

Ricardo, D. (1996) [1817]. Princípios de Economia Política e Tributação. São Paulo: Nova Cultural.

Schumpeter, J. A. (1997) [1964]. Teoria Do Desenvolvimento Econômico: Uma Investigação Sobre Lucros, Capital, Crédito, Juro e o Ciclo Econômico. São Paulo: Nova Cultural.

Sharpe, S. A. (1990). Asymmetric Information, Bank Lending, and Implicit Contracts: A Stylized Model of Customer Relationships. The Journal of Finance, 45(4), 10691087. http://doi.org/10.1111/j.1540-6261.1990.tb02427.x

Smith, A. (1996) [1776]. A riqueza das nações: investigação sobre sua natureza e suas causas. Os Economistas. São Paulo: Nova Cultural.

Stiglitz, J. E., \& Weiss, A. (1981). Credit Rationing in Markets with Imperfect Information. The American Economic Review.

Tabak, B. M., Fazio, D. M., \& Cajueiro, D. O. (2013). Systemically important banks and financial stability: The case of Latin America. Journal of Banking and Finance, 37(10), 3855-3866. http://doi.org/10.1016/j.jbankfin.2013.06.003

Wittenberg-Moerman, R. (2008). The role of information asymmetry and financial reporting quality in debt trading : Evidence from the secondary loan market \$. Journal 
of Accounting and Economics, 46, 240-260.

http://doi.org/10.1016/j.jacceco.2008.08.001. 